\title{
Temporal and Spatial changes in Crop Patterns, Use of inputs and Hydrological Alteration in the case of Fogera floodplain, Ethiopia
}

\author{
Mare Desta ( $\sim$ mare.addis@eiabc.edu.et ) \\ University \\ Gete Zeleke \\ Addis Ababa University \\ William. A. Payne \\ University of Nevada Reno \\ Wubneh Abebe \\ Bahir Dar University
}

\section{Research}

Keywords: Crop, inputs. Hydrological alteration, floodplain, Ethiopia

Posted Date: July 7th, 2021

DOI: https://doi.org/10.21203/rs.3.rs-431993/v2

License: (c) (i) This work is licensed under a Creative Commons Attribution 4.0 International License. Read Full License

Version of Record: A version of this preprint was published at Ecologies on December 13th, 2021. See the published version at https://doi.org/10.3390/ecologies2040022. 


\section{Abstract}

\section{Bauckground}

More than half of the world's population consumes rice. The area under modern rice varieties has expanded, the use of chemical fertilizers and pesticides has increased in various countries. The hydrology of wetlands are also influenced by its chemical and physical characteristics. Hence, this research focused on temporal and spatial changes in crop patterns, input usage, and hydrological change in Fogera floodplain, with the objectives: a. what are the spatial and temporal trends in crops production pattern? b. What inputs have been used in the past and present to produce rice and other crops? c. What looks like the hydrological alteration of the area? The primary data was gathered through a questionnaire, focus group discussions, interviews, and field observations. Secondary data from Landsat imageries, SWAT input data, water flow, normalized difference vegetation index, and hydrological alteration of the site were collected. To analyze data, tables, graphs, and charts percentage, mean, and correlation were used.

Result

NDVI results indicated that rice crop is growing while other variables are decreasing. artificial inputs are currently used but before the introduction of rice were not. Recession farming activities have also diminished wetland. Annual average water flow and rainfall have been trending upward. Flow of water with Nitrogen and Phosphorous has a negative correlation, with Pearson's values -0.069 and -0.072 , respectively whereas the value 0.242 indicates that nitrogen and phosphorus have a positive relationship.

Conclusion

In conclusion, these extended and intensification of farming practices have an impact on the biodiversity of fauna and flora of the area.

\section{Introduction}

Rice feeds more than half of the world's population, with 148 million hectares of land devoted to the crop in 1991, yielding 519 million tons. Rice is grown in flooded fields for all or part of the cropping season, accounting for approximately 87 percent of total rice land (Roger 1996). For millennia, wetlands, especially floodplains with fertile soils and abundant water, have been used for agriculture. Wetlands have undeniably aided the development of many significant cultures around the world, but the disadvantage is that wetlands drainage and reclamation for agriculture have become more widespread in recent years. In certain parts of the world, more than half of the floodplains have been lost, with the agricultural conversion being one of the primary causes of these ongoing wetland losses (Ramsar, FAO and IWMI 2014).

The most essential food crop, rice, grows well in flooded soil. As the area under modern rice varieties has expanded, the use of chemical fertilizer has increased in various countries (Ghosh and Ravi 2012). Rice receives around $10 \%$ of the total nitrogen fertilizer applied globally. Nitrogen is found in chemical fertilizers in the form of ammonia or nitrate. Around half of the Catla (common carp) fish died when the ammonia concentration reached $29.4 \mathrm{mg} \mathrm{NH3}-\mathrm{N} / \mathrm{L}$. Organic nitrogen fertilizers accelerated the development of fish compared to inorganic nitrogen fertilizers. The accumulation of nitrogenous compounds in rice environments triggers an unavoidable cycle of environmental hazards in rice-growing countries (Roger, Heong, and Teng 1991). Chemical pesticides used to control rice pests (microbial diseases, weeds, nematodes, snails, insects, and rodents) resulted in significantly higher grain yields.

The hydrology of the wetland, which is affected by soil, biota, and build-up materials, influences and determines the wetland's characteristics (Mitsch and Gosselink 2000). The hydrology of a wetland is influenced by its chemical and physical characteristics. The amount of oxygen in the soil, as well as the supply of nutrients and toxicants, are all affected by hydrology. Longer periods of inundation can result in longer periods of anaerobic and/or decreased conditions, limiting the

Page $2 / 30$ 
plants that can survive in general (Tiner 1993). Land use within the wetland catchment is likely to affect the state of the wetlands (Johnson et al., 1997).

Hydrology can be the most important determinant of the establishment and protection of different types of wetlands and wetland processes. It is the driving force behind the unique characteristics of wetlands (Gosselink and Turner 1979). A noticeable and important change in streamflow characteristics such as magnitude, timing, frequency, length, and rate of change of flow is referred to as hydrological alteration (Rosenberg et al., 2000). When the usual amount of water entering a wetland is decreased or raised, or when the time of saturation and inundation is prolonged, the ecosystem changes to an upland system. Flooding frequency, length, and seasonality are all factors in wetland hydrology. Frequency of inundation refers to the average amount of times a wetland is flooded in a given period. Seasonality refers to when surface water is present during the year, while length refers to how long it is present (Mitsch and Gosselink 2000).

Rice processing, as a result, necessitates long-term hydrological processes. The majority of cultivated rice is grown in floodplains, rainfed lowlands, and irrigated areas. Irrigated rice is rice that is cultivated with the addition of water to supplement natural water sources such as rainfall. Rainfed wetland rice is grown in areas where there is a need for and a desire for standing water during the growing season. Because of their high biomass production, wetlands in Ethiopia's Lake Tana region, such as the Fogera floodplain, have historically provided valuable feedstock for livestock (MEA 2005). The Fogera floodplain has been widely used for livestock grazing for centuries (IPMS 2005). For millennia, the Fogera floodplain has been extensively used for livestock grazing (IPMS 2005). Wetlands play an important ecological and hydrological role in environmental protection, as well as providing residents with a range of environmental and socioeconomic benefits (Dugan 1990).

Agriculture faces a major challenge in developing strategies to maintain production while reducing environmental impacts. The trade-off between crop production (such as rice) and water quality services and ecosystems is one of the most serious issues facing agriculture, and interest in achieving win-win outcomes through ecosystem service management is growing. Reducing trade-offs between crop production, water quality, and other habitats increase the likelihood of win-win outcomes (Qiu and Turner 2013). More research is required to determine how trade-offs can be mitigated and whether the likelihood of win-win outcomes can be increased in agricultural landscape management to encourage win-win strategies (Qiu and Turner 2013). As a result, achieving a global transition to sustainable farming would necessitate a concerted effort to respond to our population's rapid growth without jeopardizing the environment's integrity (Gomiero et al., 2011).

To increase rice production and market system, several studies were conducted in the Fogera Wetland. For example, the impact of integrated farmyard fertilizer and inorganic nitrogen $(N)$ and phosphorous $(P)$ fertilizers on rain-fed rice development, produce, and fatal moisture pressure tolerance (Tilahun et al., 2013); profitability and marketing chain of rice in Fogera Woreda (Astewel 2010); evaluation of the outcome of different time and incidence of hand weeding levels on directseeded rice (Agegnehu et al., 2013); and researchers studied the response of rice's produce and produce components to determine the optimal fertilizer levels required for increased grain production of flooded rice (Heluf and Mulugeta 2006). These studies, on the other hand, overlooked the Fogera floodplain wetland's environmental trade-offs and other ecosystem functions.

As a result of rice intensification in the wetlands of Fogera areas along the Eastern shore of Lake Tana, this research aims to identify temporal and spatial shifts in crop patterns, input use, and hydrological alteration in the Fogera floodplain. As a result, the following are the study's objectives: a. what are the spatial and temporal trends in crops production pattern in the area? b. What inputs have been used in the past and present to produce rice and other crops? c. What looks like the hydrological alteration of the area?

\section{Material And Methods}

\subsection{Description of Study Area}


The Amhara Region has a population of $17,214,056$, with 8,636,875 men and 8,577,181 women (CSA 2007). A total of $2,112,220$ people lived in the city, accounting for 12.27 percent of the total population. This region has a population density of 108.15 people per square kilometer, with a total area of $159,173.66$ square. In total, there were $3,953,115$ households in the district. As a result, each household has an average population of 4.3 individuals. The average family size in both urban and rural areas is 3.3 and 4.5 individuals, respectively.

Fogera Woreda is situated between latitudes $11^{\circ} 46^{\prime}$ and $11^{\circ} 59^{\prime}$ north and longitudes $37^{\circ} 33^{\prime}$ and $37^{\circ} 52^{\prime}$ east, at an altitude of 1,774 to 2,410 meters above sea level and a mean annual rainfall of $1,216 \mathrm{~mm}$, with long rains from June to September. As a result, the Woina-Dega (mid-latitude) agro-ecology classification is the most common. Rice is the most common crop in the Fogera wetland. Woreda, the Woreda capital, is 625 kilometers from Addis Ababa and 55 kilometers from the provincial capital, Bahir Dar. LiboKemkem Woreda borders the Woreda on the north, Dera Woreda on the south, Lake Tana on the west, and Farta Woreda on the east. (Figure 1).

Fogera Woreda is one of the surplus crop-producing areas, with a high potential for rice production. The floodwaters that collect around Lake Tana and the two major rivers, Rib and Gumara, are channeled through this region. Rivers carry eroded soil from highland to the plains. The soil tends to be rich in nutrients and deep in depth. In the study area, rice is planted on lower slopes where the water table rises to the surface for a long time during the cropping season. Rice is also irrigated with water diverted from streams in a drainage system's upper reaches. The sum of irrigated water, on the other hand, is usually negligible. The primary sources of water for rice plants in Fogera and the surrounding Woredas are rainfall, runoff, and underground water. In the processing of rain-fed rice, bunds are commonly used. During the growing season, the bunds are used to hold floodwater and rainwater out (IPMS, 2005; Abaye, 2007).

On the top left side of the map, Ethiopia is depicted with a geographical map of the Amhara region; on the bottom left side, the Amhara Region and regional zones are depicted; on the right bottom, Fogera Woreda that comprises only 10 biosphere reserve kebeles is depicted; and on the top right side, the study site is depicted.

\subsection{Sampling and data collection}

The research was carried out in the Fogera Wetland on Lake Tana's Eastern Shore. According to the preliminary assessment conducted during a field visit to some Fogera floodplains, the wetlands of Lake Tana are highly vulnerable to environmental trade-offs as a result of various development activities such as rice intensification, fishing, sand extraction, and illegal recession cultivation. Fogera is one of the wetland areas surrounding the Lake Tana water body that has large wetlands that are heavily used for rice intensification. As a result, the wetland is vulnerable to environmental trade-offs. Besides, the Fogera floodplain currently has the two largest rivers that feed Lake Tana. As a result, the Fogera floodplain has been chosen for further investigation and long-term use of the wetland resource.

There are 27 Kebeles in Fogera Woreda, including Woreta and Amed ber (Alember) area. Sample kebeles were chosen with care for the analysis. The rice-producing kebeles closest to the Lake Tana floodplain are first identified. In this situation, there were five kebeles. The analysis included all five kebeles, with sample households drawn proportionally from each kebele (Table 1). The household size determined by the following formula Yamane (1967) approach

$$
n=\frac{N}{1+N(\boldsymbol{e})^{2}}
$$

Hence, $\mathrm{n}=$ Sample; $\mathrm{N}=$ Population; $\mathrm{e}=$ Error term (5\%)

Table 1 Stratified sample population from each sample kebele 


\begin{tabular}{llll} 
No & Name of Kebele & Total Household* & Sample $^{\star \star}$ \\
\hline 1 & Nabega & 2,283 & 87 \\
\hline 2 & Shina & 2136 & 81 \\
\hline 3 & Kidis Hana & 1790 & 69 \\
\hline 4 & Shaga & 1515 & 57 \\
\hline 5 & Wagetera & 2398 & 91 \\
\hline \multicolumn{2}{l}{ Total } & 10,122 & 385
\end{tabular}

*CSA, 2007

** Sample for each Kebele $=\frac{\text { Total number of Households in a keble } x \text { Total sample housholds }}{\text { Total Hoseholds of all sample kebles }}---$ (EQ2)

On the other hand, focus group discussions (FGD) participants were chosen based on their kebele's representatives. Furthermore, farmers were chosen for interviews based on their living and working experience in wetland areas, as well as their expertise in this field. The information used to choose the three farmers who were interviewed was given by a developing agent who was working with them.

Questionnaires, interviews, focus group discussions (FGDs), and field observations were used to gather data for this report. Furthermore, data was gathered from secondary sources such as Landsat images, SWAT input data (climate data such as rainfall, temperature, wind speed, relative humidity, and DEM (digital elevation model) soil map (USGS.gov) shapefile, water flow data (MoW), and normalized difference vegetation index (NDVI) data (MODIS from https://doi.org/10.5067/ASTER/ASTGTM.003). Moreover, additional data were collected to see the hydrological alteration of the area, and then water flows data taken from the Ethiopian Ministry of Water. Other documents were also collected from different offices (published and unpublished), articles from journals.

Questionnaire: socio-economic data (for example, grazing land, grazing systems, land for rice production, farmland scale, recession farming, crop type, inputs, and crop yield in various years, agricultural activities such as recession farming). Besides, data was gathered from experts in the agriculture office at various levels using a questionnaire.

Interview: The state of wetland resource use and management, as well as the loss and benefit of wetland resources as a result of rice price fluctuations. Ethio-wetland and Natural Resource Management Association were also interviewed about support and other activities related to wetlands in the Fogera floodplain.

FGD: data about land use, the driving cause of land-use change, wetland resources, presence and absence of the wetland resources (plants), and wetland big animals were collected.

Field observation and GPS: Field observations were made to collect data about the land use of the study area using the checklist. GPS was also used to collect data to do ground verification to generate NDVI data.

\subsection{Methods of data analysis}

Data that were collected via questionnaires were summarized through tables, graphs, and charts. These data were analyzed through percentage, mean, and correlation. Correlations were used for water flow in m3/s, Nitrogen ( $N$ ) flow in m3/s, and Phosphorous $(P)$ flow in $\mathrm{m} 3 / \mathrm{s}$. Moreover, correlation and regression were employed for the streamflow out m3/s, No3 flow out and $\mathrm{P}$ flow out to predict the variables that indicate water pollution Indicators of Hydrological Alteration (IHA) were also generated through the software IHA Version 7.1. Furthermore, document content analysis was employed and triangulated with the analyzed result of the questionnaire, interview, FGD, and observation. On the other hand, image processing and 
analysis were done using ArcGIS10.4 software to generate NDVI data for the years 2000, 2009, and 2018 to see an expansion of rice in the wetlands of Fogera.

This NDVI on the images was used to generate the rice, dense vegetation and water bodies, and other small grass areas within a wetland using a suitable threshold for (rice 4001-7158, dense vegetation above 7158, water and others less than 4001) through ArcGIS 10.4. These are important to identify different indices for quantification of wetland characteristics through NDVI developed by different researchers (Tucker and Sellers 1986). Details of these indices formula are given below. These indices were generated using ArcGIS 10.4 image processing software and stacked as layers. Various combinations of the indices/spectral bands were used to identify the wetland features for the year 2000, 2009, and 2018 (Figure 3a, 3b, and 3c)

$\mathrm{NDVI}=\frac{\text { NIR-Red }}{\text { NIR+Red }}$

Where NIR is the datum in the near-infrared and Red is in the red area. The maps were represented using the color scale, where the lowest NDVI was associated with black, gradually changing to gray and white, the latter with values closer to 1 (González-Betancourt 2018).Results and Discussion

\section{Results And Discussion}

\subsection{Spatial and Temporal Trends in Crops Production Pattern in the area}

As shown in Table 2, the spatial and temporal patterns in the area's crop production pattern are shown based on three classes, with the main emphasis on identifying the rice crop's condition. When the time series is explored in the google earth engine, the rice crop was indicated in increasing trends whereas dense vegetation, water, and other small vegetation are showing in a decreasing trend based on the calculated results of the NDVI of rice crop, vegetation, water, and others in the year 2000, 2009 and 2018 (Figure 2 and Table 2). The graph also clearly indicated the increasing and decreasing trends of classes. The negative slope expresses the decreasing trend while the positive slope indicates the increasing trend.

Table 2 Summary of NDVI

\begin{tabular}{llll} 
class type & 2000 & 2009 & 2018 \\
\hline dense vegetation & 0.269 & 0.012 & 0.080 \\
\hline Rice & 111.266 & 134.69 & 135.23 \\
\hline water and others & 0.333 & 0.356 & 0.283
\end{tabular}

Furthermore, as it is shown in Figure 3a, the NDVI values in 2000 for dense vegetation, rice, and water, and others are 2691.22 ha, 11126.6ha, and 3328.02 ha respectively. In Figure 3b, the NDVI value in 2009 for dense vegetation is 120.06 ha, for rice 13469.4 ha, and water and others are 3556.36 ha. Moreover, in 2018 as it is indicated Table 2 and shown in Figure 3c, the value for dense vegetation, rice and water, and others are $796.086 \mathrm{ha}, 13523.4 \mathrm{ha}$, and 2826.27 ha respectively. Based on these calculated data, the figures clearly showed that there is an increase in the area coverage for rice while dense vegetation and water and others are showing a decline. The spatial and temporal patterns of rice crop production have increased by 2396.8 ha whereas water and others are decreased by -1895.134 ha and -501.75 ha in the year 2000 to 2018 , respectively.

Accordingly, it is indicated in Table 3, the sampled respondent mentioned that the size of their farmland before the introduction of rice was 159.75 ha but after the introduction of rice this number flipped to $284.75 \mathrm{ha}$. The difference is 125 ha.

Table 3 Expansion of farmland for rice production 


\begin{tabular}{|c|c|c|c|c|c|c|c|c|c|}
\hline \multirow[t]{3}{*}{ Sample Kebeles } & \multirow{3}{*}{$\begin{array}{l}\text { No of sample } \\
\text { Respondents }\end{array}$} & \multirow{2}{*}{\multicolumn{2}{|c|}{$\begin{array}{l}\text { Their } \\
\text { farmland }\end{array}$}} & \multicolumn{6}{|c|}{ Size of their farmland in Timad } \\
\hline & & & & & \multicolumn{5}{|c|}{1 timad $=0.25$ ha } \\
\hline & & Yes & No & $\begin{array}{l}\text { Before } \\
\text { rice }\end{array}$ & $\%$ & $\begin{array}{l}\text { After } \\
\text { rice }\end{array}$ & $\%$ & Increased & $\%$ \\
\hline Kidest Hana & 69 & 68 & 1 & 124 & 19.5 & 221 & 19.4 & 97 & 19.3 \\
\hline Shina & 81 & 81 & 0 & 130 & 20.5 & 234 & 20.5 & 104 & 20.6 \\
\hline Shaga & 57 & 57 & 0 & 95 & 15 & 175 & 15.4 & 80 & 15.9 \\
\hline Wagetera & 91 & 91 & 0 & 146 & 23 & 261 & 22.9 & 115 & 22.8 \\
\hline Nabega & 87 & 87 & 0 & 140 & 22 & 248 & 21.8 & 108 & 21.4 \\
\hline $\begin{array}{l}\text { Gross cropped } \\
\text { area }\end{array}$ & 385 & 384 & 1 & 635 & 100 & 1139 & 100 & 504 & 100 \\
\hline
\end{tabular}

Table 4 showed that about $88 \%$ of sampled respondent farmers responded they do have sufficient farmland to produce more rice crops to satisfy their family's needs and for sale. On the other hand, about $12 \%$ of the respondents said that they have sufficient farmland to produce rice only to satisfy their family needs.

Table 4 Land for rice production

No of Kebeles A farmland sufficiency to produce food for your families

\begin{tabular}{llll}
\cline { 2 - 3 } & No of respondent & Yes & No \\
\hline Kidest Hana & 69 & 62 & 7 \\
\hline Shina & 81 & 71 & 9 \\
\hline Shaga & 57 & 52 & 5 \\
\hline Wagtera & 91 & 77 & 14 \\
\hline Nabega & 87 & 75 & 12
\end{tabular}

Respondents were asked about their previous production style before the introduction of rice and they reported that they produced different crops in the study areas. These were Teff (Eragrostis tef), maize (Zea mays L.), noug (Guizotia abyssinica), finger millet (Eleusine coracana), chickpea (Cicerarietinum), lentil (Lens culinaris), grass pea (Lathyrus sativus), green pepper (Capsicum spp.) and Barely (Hordeum Vulgare) in small amount and animal rearing at a large extent. The respondents were explained that these crops were also produced far away from the wetlands in the study site.

This time most of the respondents have been engaged in rice production during the summer season while in the winter season, they started to produce horticultural crops of vegetables like an onion (Allium cepa), garlic (Allium sativum), and tomatoes (Solanum Lycopersicum). They are grown under small-scale irrigation.

\section{Cultivated area and crop yield produced for the year 2014 and 2015 cropping season}

Regarding the area cultivated for the wetlands of Fogera floodplain, the two years data showed that cultivated area coverage of the rice crop was 245.25 ha and 284.75 ha in the year 2014 and 2015, respectively (Table 5). It is also mapped that in 
Figure 4, the land-use coverage for rice and other land use for the year 2013, 2015, and 2016, the result revealed the coverage for rice has shown increment.

Table 5 The area cultivated and crop yield produced for the year 2014 and 2015

Rice

\begin{tabular}{|c|c|c|c|c|c|c|c|c|}
\hline \multirow{2}{*}{$\begin{array}{l}\text { Name of } \\
\text { sample } \\
\text { kebele }\end{array}$} & \multirow{2}{*}{$\begin{array}{l}\text { No of } \\
\text { sample } \\
\text { respondent }\end{array}$} & \multicolumn{3}{|l|}{2014} & \multicolumn{4}{|l|}{2015} \\
\hline & & $\begin{array}{l}\text { Cultivated } \\
\text { land in } \\
\text { Timad= } \\
(0.25 \text { ha })\end{array}$ & $\begin{array}{l}\text { Total } \\
\text { cultivated } \\
\text { land in } \\
\text { ha }\end{array}$ & $\begin{array}{l}\text { Farmland } \\
\text { per } \\
\text { sample } \\
\text { house } \\
\text { hold }\end{array}$ & $\begin{array}{l}\text { Cultivated } \\
\text { land in } \\
\text { Timad= } \\
(0.25 \mathrm{ha})\end{array}$ & $\begin{array}{l}\text { Total } \\
\text { cultivated } \\
\text { land in } \\
\text { ha }\end{array}$ & $\begin{array}{l}\text { Farmland } \\
\text { per } \\
\text { sample } \\
\text { house } \\
\text { hold }\end{array}$ & $\begin{array}{l}\text { Increment } \\
\text { in ha }\end{array}$ \\
\hline $\begin{array}{l}\text { Kidest } \\
\text { Hana }\end{array}$ & 69 & 184 & 46 & 0.66 & 221 & 55.25 & 0.8 & 9.25 \\
\hline Shaga & 81 & 208 & 52 & 0.64 & 234 & 58.5 & 0.72 & 6.5 \\
\hline Shina & 57 & 144 & 36 & 0.63 & 175 & 43.75 & 0.77 & 7.75 \\
\hline Wagetera & 91 & 225 & 56.25 & 0.62 & 261 & 65.25 & 0.72 & 9 \\
\hline Nabega & 87 & 220 & 55 & 0.63 & 248 & 62 & 0.71 & 7 \\
\hline
\end{tabular}

\section{Practice on cropping pattern}

About $89 \%$ of the sampled household respondents reported that the types of cropping pattern practiced are mono-cropping whereas about $11 \%$ of sampled respondents said that they practiced crop rotation (Table 6 ). The later respondents who pracice crop rotation explained their reason why they practiced it? This is because their farmland is far away from the floodplain which is located on the upland side of the Fogera floodplain.

Table 6 Types of cropping pattern

\begin{tabular}{llllll}
\multicolumn{2}{l}{ type of cropping pattern do you practice } & & & \\
\hline No of kebeles & No sample respondents & Mono cropping & Crop rotation & Intercropping & Other \\
\hline Kidest Hana & 69 & 62 & 7 & 0 & 0 \\
\hline Shaga & 81 & 69 & 12 & 0 & 0 \\
\hline Shina & 57 & 51 & 6 & 0 & 0 \\
\hline Wagetera & 91 & 81 & 9 & 0 & 0 \\
\hline Nabega & 87 & 79 & 8 & 0 & 0
\end{tabular}

\section{Past and present use of inputs to produce rice and other crops}

The respondent farmers were asked about the methods to maximize yield. The entire respondent responded that the methods to maximize yield are applying artificial inputs such as fertilizer, improved seed, insecticide, and herbicide (Table 7). Furthermore, the other methods are the expansion of rice farming through encroaching wetlands and communal grazing lands. Most of the sampled household farmers said that application of insecticide has been used for most crops of chickpea (Cicer arietinum) and grass pea (Lathyrus sativus) sowed after the harvest of rice (Oryza sativa) crop. The sampled respondents were asked regarding the inputs used for other crops in the previous time. They reported that all respondents were not used artificial input rather they used manure for the production of maize (Zea mays L.) and green pepper (Capsicum 
spp.). Besides, a fallowing system without any inputs was used. As it is reported in the FGD and interview, the main reasons were the population was very small in number, rice and other artificial inputs were not introduced and adapted. It is also explained in the discussion, in previous times their farmlands were better fertile than the current one. Besides, it is reported by sampled household the cause for the reduction of yield in the study area was the reduction of soil fertility and upland erosion that brought sand and other unfertile soil particles like gravel, which reduce the amount of water in the wetland of study area. Hence, in the study area, it has been started to use artificial input for their farmland to yield.

Table 7 Inputs used for the production of crops

If there is an increase in production, what are the causes

\begin{tabular}{lllllllll}
$\begin{array}{l}\text { No of } \\
\text { kebeles }\end{array}$ & $\begin{array}{l}\text { No of } \\
\text { respondents }\end{array}$ & Fertilizers & manure & $\begin{array}{l}\text { improved } \\
\text { seed }\end{array}$ & fallowing & $\begin{array}{l}\text { Crop } \\
\text { rotation }\end{array}$ & $\begin{array}{l}\text { using } \\
\text { insecticides }\end{array}$ & $\begin{array}{l}\text { using } \\
\text { herbicides }\end{array}$ \\
\hline $\begin{array}{l}\text { Kidest } \\
\text { Hana }\end{array}$ & 69 & 69 & 0 & 69 & 0 & 0 & 69 & 69 \\
\hline Shaga & 81 & 81 & 0 & 81 & 0 & 0 & 81 & 81 \\
\hline Shina & 57 & 57 & 0 & 57 & 0 & 0 & 57 & 57 \\
\hline Wagetera & 91 & 91 & 0 & 91 & 0 & 0 & 91 & 91 \\
\hline Nabega & 87 & 87 & 0 & 87 & 0 & 0 & 87 & 87
\end{tabular}

\subsection{Artificial Inputs Used}

According to Figure 5 , about $45.5 \%$ of respondents already started to apply fertilizer, $23 \%$ of the respondents started to use improved seed and $77 \%$ of sampled households still use local seed. About $95 \%$ of the sampled household respondents said that they used pesticides when pests occurred in their area (eg. See photo showed in Figure 6). This spraying of pesticides could kill insects and those insects would be eaten by birds. So, the birds could be affected. Herbicides are used to control weeds in their farmland by about $64 \%$ of the respondents.

As Table 8 showed, almost $100 \%$ of sampled household respondents responded that the benefits recognized from using artificial inputs were increased yield of rice. They also said that the amount of hays getting after trashed of the crops for livestock feed was very good.

Table 8 Recognition the importance of inputs use

benefits did you recognize from using artificial inputs

No of kebeles No sample respondents Increase yield decreasing yield No change

\begin{tabular}{lllll}
\hline Kidest Hana & 69 & 68 & 0 & 0 \\
\hline Shaga & 81 & 81 & 0 & 0 \\
\hline Shina & 57 & 57 & 0 & 0 \\
\hline Wagetera & 91 & 91 & 0 & 0 \\
\hline Nabega & 87 & 87 & 0 & 0
\end{tabular}


As Table 9 showed that about (74.3\%) household respondents reported artificial inputs has brought water pollution (from their physical observation point of view), while about (72.5\%), (96.1\%), (73.2\%) and (72.7\%) reported that there was a reduction of the number of birds, bee's colony, fish availability in the wetlands and the Lake Tana, and other insects like reptiles, amphibians in the wetlands of the study area.

Table 9 Negative Impacts of Artificial Input Used

\begin{tabular}{|c|c|c|c|c|c|c|}
\hline \multirow{3}{*}{$\begin{array}{l}\text { No of } \\
\text { kebeles }\end{array}$} & \multirow{3}{*}{$\begin{array}{l}\text { No sample } \\
\text { respondents }\end{array}$} & \multicolumn{5}{|c|}{ Do you recognize the negative impacts from using artificial inputs } \\
\hline & & $\begin{array}{l}\text { Water } \\
\text { pollution }\end{array}$ & $\begin{array}{l}\text { Reduction of } \\
\text { birds }\end{array}$ & $\begin{array}{l}\text { Reduction of } \\
\text { bees }\end{array}$ & $\begin{array}{l}\text { Reduction of } \\
\text { fish }\end{array}$ & $\begin{array}{l}\text { Reduction } \\
\text { of }\end{array}$ \\
\hline & & & & & & $\begin{array}{l}\text { other } \\
\text { insects }\end{array}$ \\
\hline $\begin{array}{l}\text { Kidest } \\
\text { Hana }\end{array}$ & 69 & 53 & 47 & 55 & 50 & 48 \\
\hline Shaga & 81 & 64 & 63 & 80 & 63 & 63 \\
\hline Shina & 57 & 41 & 41 & 57 & 41 & 41 \\
\hline Wagetera & 91 & 66 & 66 & 91 & 66 & 66 \\
\hline Nabega & 87 & 62 & 62 & 87 & 62 & 62 \\
\hline
\end{tabular}

\section{Recession farming}

As indicated in Table 10, about $22 \%$ of the sampled household respondent farmers said that they practice recession farming. That means when the water of wetland and Lake retreated (Figure 7). This $22 \%$ of respondents also explained their experience in producing maize in the surrounding wetlands and Lake Tana when the amount of water retreats in the dry season after harvesting their rice crop. Whereas, about $78 \%$ of the sampled households were not using recession farming because their farm areas are not close to the wetlands and Lake Tana.

Table 10. Recession farming

No of sample kebeles

Do you produce crops in the form of recession farming

\begin{tabular}{llll} 
& \multirow{2}{*}{$\mathrm{N}^{\circ}$ of sample respondents } & \multicolumn{2}{c}{} \\
\cline { 4 - 4 } & & Yes & No \\
\hline Kidest Hana & 69 & 11 & 58 \\
\hline Shaga & 81 & 16 & 65 \\
\hline Shina & 57 & 8 & 49 \\
\hline Wagetera & 91 & 25 & 66 \\
\hline Nabega & 87 & 23 & 64
\end{tabular}

\section{Impacts of recession farming}

Respondents were also asked about the impacts of recession farming on wetland and Lake resources. According to their physical observation, $100 \%$ of respondents said that the wetland and Lake resources are reduced through time because of recession farming activities in the study area, especially papyrus, grass, birds, amount of water, the color of water, increase 
siltation, turbidity of the water, etc. Hence, farmers were trying to maximize their productivity through the expansion of recession farming at the expense of wetlands and Lake Tana in the study area.

The respondent farmers interviewed and FGD participants were also asked for triangulation about what changes have been observed in wetlands and water resources in their kebele. According to their response in physical observation, their explanations summarized that there was a reduction of water level in the wetland, fish, loss of papyrus and other different grass species, drying of wetland, hippopotamus in number, birds, different insects in the wetlands, etc.

The resources of wetlands reduced over time has been ranked by respondents, As Table 11 illustrated below, respondent farmers were asked to respond regarding the natural resource reduction around the wetland of Fogera. The questionnaire has different multiple choices such as the situation of the following resources like papyrus, fish, sand, birds, grass, amount of water, and hippopotamus. According to their observation, the respondent farmers tried to put the reduction of wetland resources in order of rank (Table 11). Based on the respondents' choice summary, the whole sampled respondents (385) said that papyrus has reduced first and the others, such as fish, grass, amount of water, birds, hippocampus and sand reduction have been presented 2nd, 3rd, 4th, 5th, 6th and 7th ranked respectively (Table 11). These weighted ranks indicated us papyrus is the first highly reduced resource and sand is the least reduced resource.

Table 11 Rank of wetland and Lake Tana resources 
Description of wetland resources
Papyrus Fish Sand Birds Grass Amount Hippopotamus

Resource

Rank of

water
Wetland resources highly reduced is ranked from the smallest number 1 to the large number 7 .

$\mathrm{eg}$, if 1 is selected, the resource is highly reduced.

$\begin{array}{llllllll}\begin{array}{l}\text { First }= \\ 1\end{array} & 385 & 0 & 0 & 0 & 0 & 0 & 0 \\ \begin{array}{l}\text { Second }= \\ 2\end{array} & 0 & 135 & 5 & 7 & 191 & 47 & 0 \\ \begin{array}{l}\text { Third }= \\ 3\end{array} & 0 & 43 & 63 & 10 & 95 & 171 & 3 \\ \begin{array}{l}\text { Fourth }= \\ 4\end{array} & 0 & 178 & 4 & 117 & 14 & 60 & 12 \\ \begin{array}{l}\text { Fifth }= \\ 5\end{array} & 0 & 27 & 30 & 189 & 15 & 71 & 53 \\ \begin{array}{l}\text { Sixth } \\ 6\end{array} & 0 & 1 & 38 & 32 & 28 & 13 & 273 \\ \begin{array}{l}\text { Seventh } \\ =7\end{array} & 0 & 1 & 245 & 30 & 42 & 23 & 44\end{array}$

In this table, the data is the weighted value for each resource responded by sampled respondents. eg, 385 sampled respondents give rank for each resource.
Resource

Papyrus

Fish

Rank

\section{1}

$\begin{array}{ll}1 & 385 \\ 2 & 0\end{array}$

Rank value *each value given by respondents eg, $1 * 385=$ 385 continuous like this

Weighted Sum Total

\begin{tabular}{|c|c|c|c|c|c|c|c|c|}
\hline & & & & & & & & \\
\hline & 2 & 0 & 270 & 10 & 14 & 382 & 94 & 0 \\
\hline & 3 & 0 & 129 & 189 & 30 & 285 & 513 & 9 \\
\hline & 4 & 0 & 712 & 16 & 468 & 56 & 240 & 48 \\
\hline & 5 & 0 & 135 & 150 & 945 & 75 & 355 & 265 \\
\hline \multirow{2}{*}{$\begin{array}{l}\text { Rank value *each value given } \\
\text { by respondents eg, } 1 * 385= \\
385 \text { continuous like this }\end{array}$} & 6 & 0 & 6 & 228 & 192 & 168 & 78 & 1638 \\
\hline & 7 & 0 & 7 & 1715 & 210 & 294 & 161 & 308 \\
\hline \multirow[t]{2}{*}{ Weighted Sum Total } & & 385 & 1259 & 2308 & 1859 & 1260 & 1441 & 2268 \\
\hline & Rank & $1^{\text {st }}$ & $2^{\text {nd }}$ & $7^{\text {th }}$ & $5^{\text {th }}$ & $3^{\text {rd }}$ & $4^{\text {th }}$ & $6^{\text {th }}$ \\
\hline
\end{tabular}

\section{Wetland conservation issues of Fogera}

Sampled household respondents were asked to answer regarding the wetland conservation issues. About $100 \%$ of sampled household respondents responded that they strongly want to conserve the wetlands of Fogera in the study area and the surrounding of Lake Tana. They reported that the benefits of the conservation of wetland of Fogera can save the resources mentioned such as papyrus, fish, birds, grass, getting pure water, moderate climate, reduction of flooding, increasing soil fertility, high amount of water, increase vegetation, Provide hatchery and nursery areas for the fish, erosion control, nutrient retention, groundwater recharge, recreational activities, Habitat for hundreds of species of animals and birds, the first line of defense against pollution from surface water runoff, increasing different insects like bees, etc. Generally, the biodiversity of the wetlands would increase. From these resources, the local people can wisely extract and use the previous style of the community. 
The respondents also explained the demerit of conservation of wetlands, the whole respondents said that even though the merits of the conservation of the wetland and the Lake resources have been better, there was also the demerits of conservation of wetland summarized as the following: no use of wetlands as they want especially illegal expansion of rice agriculture to the wetlands. Recession farming is considered as a disadvantage for certain users of recession farming because they said that increasing the number of hippopotamus and birds could damage their crops, there would no freely fish harvest in the wetlands and the Lake (Figure 8), there would not be free grazing that some of the people consider as a demerit.

The sampled household farmers, interviewed respondents and FGD participants were asked regarding the practice that was implemented in their floodplain in the study kebeles before the introduction of rice, their explanation was summarized as follows: most of the floodplain was used for grazing purpose for Fogera known indigenous cattle breed, the wetland areas were covered by papyrus vegetation, which was used for different purpose such as for roof thatching, for making of the mat, for the home fence, for making traditional fishing traps for fishing locally and boat making for local transportation, use of leaf of papyrus during the ceremony, Grass for roof thatching, Fishing site, some types of crops like noug, Green pepper, and finger millet, "Senele" (Butia Capitata) used for making a mat, raincoat, hut used as a cover for the dead person during his time of burial, Reeds used for making rope, brooms (Cleaning materials used a brush indicated in the left) (Figure 9).

The sampled respondent household farmers were asked regarding their observation whether there was a significant land-use change observed in wetland areas. The entire sampled respondent household farmers were responded that yes, there was a significant land-use change in the study sample kebeles. The interviewed farmers and FGD participants have also supported their ideas.

The main reasons explained for the change observed were scarcity of agricultural land especially the introduction of rice crop encouraged the local people looking for additional farmlands to produce more rice, population growth, the tragedy of the commons (the wetland areas and the borders of Lake Tana were common resources that everyone can access with no controlling mechanism) and expansion of recession farming around the wetland areas, grazing lands, and Lake Tana to produce maize, tomato, onion, teff, etc. Therefore, according to their explanation, most of the wetland, grazing land, and forest land changed into agricultural land-use systems. These ideas have been substantiated by land use land cover change detection through Landsat image classification of 1973 and 2014 that showed most of the different land-use systems changed and incorporated into agricultural land-use systems.

Sampled household farmers were also asked regarding the effects of land-use changes to the wetland and Lake Tana resources to say yes or no. The whole sampled household farmer respondents said yes and this changing of the land-use system has brought the reduction of wetland and lake resources. The reduction of those wetland and lake resources has brought the consequences of negative impacts on the wetlands and Lake Tana. The negative impacts explained not only by the sampled household respondents but also by the interviewed and FGD participants explained that the seasonal overflow water, reduction of the number of resources like birds (loss of recreation and aesthetic situation of the area), loss of papyrus vegetation, the turbidity of the wetland and Lake water (physical color change observed), siltation problem and loss of reeds has been observed in the study site according to their explanation. These problems have been increasing over time in the study site.

\subsection{Hydrological Alteration of the area and its driving force}

As Figure 10 illustrated, the annual rainfall taken from the surrounding meteorology station and the areal rainfall of the study site has a similar pattern. Yearly average water flow and rainfall of the study site have also shown an increasing trend with positive slope values $y=0.0093 x+3.3638, R^{2}=0.0659$ and $y=0.0093 x+3.3638 R^{2}=0.0762$ respectively (Figure 11). As indicated in 35 years flow average generated through (IHA) for the study area, seasonal variation of the average flow has observed (Figure 12). This is because the season from September-July is a rainy time in the area and the season from December-October gets some rainfall in addition to that the rivers are not dry and have a good flow. Generally, looking the

Page $13 / 30$ 
variability of annual water flow is due to seasonal variation of rainfall in the area. Figure 13 has also illustrated that there are similar patterns of water flow, No3, and Phosphorus in the study site.

As Table 12 illustrated summary statistics for the correlation of water flow, Nitrogen, and Phosphorous, the mean and standard deviation of water flow is 31.276 and 6.134 respectively. This is greater than the mean and standard deviation of Nitrogen $(\mathrm{N})$ and Phosphorous $(\mathrm{P})$. In the Pearson correlation matrix, the value of water flow in $\mathrm{m} 3 / \mathrm{s}$ with $\mathrm{N}$ in $\mathrm{m}^{3} / \mathrm{s}$ and $\mathrm{P}$ in $\mathrm{m}^{3} / \mathrm{s}$ is -0.069 and -0.072 respectively. These have negative relationships whereas the correlation between $N$ in $\mathrm{m} 3 / \mathrm{s}$ and $P$ in $\mathrm{m} 3 / \mathrm{s}$ has a positive correlation with the value 0.242 (Table 13).

Table 12 Summary statistics for correlation of Flow, $\mathrm{N}$ and $\mathrm{P}$

\begin{tabular}{llllllll} 
Variable & Observations & $\begin{array}{l}\text { Obs. with missing } \\
\text { data }\end{array}$ & $\begin{array}{l}\text { Obs. without missing } \\
\text { data }\end{array}$ & Minimum & Maximum & $\begin{array}{l}\text { Mean } \\
\text { Std. } \\
\text { deviation }\end{array}$ \\
\hline Flow m ${ }^{3} / \mathrm{s}$ & 35 & 0 & 35 & 18.670 & 42.280 & 31.276 & 6.134 \\
\hline $\mathrm{N} \mathrm{m}^{3} / \mathrm{s}$ & 35 & 0 & 35 & 0.040 & 2.830 & 0.911 & 0.651 \\
\hline $\mathrm{P} \mathrm{m}^{3} / \mathrm{s}$ & 35 & 0 & 35 & 0.170 & 0.360 & 0.261 & 0.047
\end{tabular}

Table 13 The correlation matrix

\begin{tabular}{|c|c|c|c|}
\hline Variables & Flow $\mathrm{m}^{3} / \mathrm{s}$ & $\mathrm{N} \mathrm{m}^{3} / \mathrm{s}$ & $\mathrm{P} \mathrm{m}^{3} / \mathrm{s}$ \\
\hline Flow $\mathrm{m}^{3} / \mathrm{s}$ & 1 & -0.069 & -0.072 \\
\hline $\mathrm{N} \mathrm{m}^{3} / \mathrm{s}$ & -0.069 & 1 & 0.242 \\
\hline $\mathrm{P} \mathrm{m}^{3} / \mathrm{s}$ & -0.072 & 0.242 & 1 \\
\hline
\end{tabular}

The image of the correlation matrix indicates clearly that the negative and positive correlation of each variables (Figure 13).

Where, Var1 $=$ Flow in $\mathrm{m}^{3} / \mathrm{s}, \operatorname{Var} 2=\mathrm{N}$ in $\mathrm{m}^{3} / \mathrm{s}$ and $\operatorname{Var} 3=\mathrm{P}$ in $\mathrm{m}^{3} / \mathrm{s}$

The correlation graph below also supports the correlation matrix image above (Figure 13). The correlation matrix graphs have also illustrated that how the relationship of variables (flow in $\mathrm{m}^{3} / \mathrm{s}, \mathrm{N}$ in $\mathrm{m}^{3} / \mathrm{s}$ and $\mathrm{P}$ in $\mathrm{m}^{3} / \mathrm{s}$ ) interacted negatively and positively (Figure 14).

\subsection{Discussion}

\section{Spatial and Temporal Trends in Crops Production Pattern}

Based on the measured results of the NDVI of rice crop, vegetation, water, and others (like small grasses) in the years 2000, 2009, and 2018, the rice crop showed a growing trend while dense vegetation, water, and others (like small grasses) showed a decreasing trend. Rice crop production has increased by 2396.8 ha in both space and time, while water and other resources have decreased by -189 ha. This is supported by the fact that wetlands are characterized by extensive and intensive cultivation, which includes more land for rice production (Gebrekidan 2014). Furthermore, people in the study area tend to 


\section{The area cultivated and crop yield produced for the year 2014 and 2015 cropping season}

The results showed that for the cropping seasons of 2014 and 2015, the area cultivated and crop yield produced increased. Furthermore, the land-use coverage for rice and other land uses via the map for the years 2013, 2015, and 2016 substantiates this notion (Figure 5). According to IPMS (2005), the rice production area had increased, and farmers in seasonally flooded areas wanted to increase their rice acreage and production because the price of rice had tripled, further stimulating interest in rice production.

\section{Practice on cropping pattern}

Mono cropping is the most common cropping pattern recorded by the majority of household respondents in the study wetland areas. This result is consistent with the findings of (Tilahun et al., 2012). We found that the introduction of rice has changed the production system, especially in the wetlands of the Fogera floodplain, from livestock-dominated to ricedominated over the last century.

\section{Past and present use of inputs}

Before the introduction of rice, both respondents said they used manure instead of artificial input to grow maize (Zea mays L.) and green pepper (Capsicum spp.). According to the FGD and interview session, the key factors were that artificial inputs were unknown and the soil was extremely fertile. Previously, no organic fertilizer was used by farmers (Tegegne and Mathias 2019). Currently, he explained that all farmers apply nitrogen-based fertilizer and up to $65 \%$ of the farmers apply phosphorusbased fertilizer. Fertilizer is applied to the rice field at different stages of growth either two or three times depending on the availability of fertilizer in the district. They use both DAP and UREA (Tegegne and Mathias 2019). Their farmlands were more fertile in the past than they are now, according to FGD participants. Furthermore, soil fertility depletion and upland erosion added sand and other unfertile soil particles, such as gravel, to the study area's wetland, decreasing the amount of water in the wetland. As a result, farmers in the study region have begun to use artificial inputs (fertilizer, improved crop, insecticide, and herbicide) on their farmland to increase productivity. They use DAP as well as UREA (Tegegne and Mathias 2019). As a result, the biodiversity of the Fogera floodplain wetlands has decreased. For example, before the use of artificial fertilizers, moist grasslands and herbaceous fens in Europe were used for grazing and hay-making. Rice has historically been grown in heavily transformed environments with rice paddies and a human-controlled water regime in other parts of the world. Rice cultivation allowed for a landscape rich in diversity, particularly in macroinvertebrates, fish, and waterfowl, until the early twentieth century (Kawano 2000; Shimoda 2007). However, as a result of the intensification of agricultural practices associated with the 'green revolution in the second half of the twentieth century, fertilizer and pesticide use has skyrocketed, resulting in a drastic rise in pesticide and fertilizer use. Summarizing, intensive agricultural use of wetlands has changed their ecological character significantly, as crop growth and livestock raising necessitate reclamation initiatives. Biodiversity has also been significantly impacted in such wetland areas, and significant portions can no longer qualify as wetlands. However, since low-intensity cultivation occurs in wetlands, requiring a regime of extensive use without fertilizers or pesticides, the landscape diversity of the wetland environment can be high, although the species composition and setting vary significantly from that of its natural state. Many of the species have been destroyed out by the agricultural intensification of the twentieth century, which included the use of fertilizers and pesticides (Millennium Ecosystem Assessment 2005).

\section{Artificial Inputs Used}


Farmers have already begun to use artificial inputs such as fertilizer, improved crop, pesticides, and herbicides, according to the sampled respondents. This is supported by the findings of (IPMS 2005), which found that improving agronomic practices increased rice yields (weed control, use of fertilizers and pest and disease control). Farmers reported increased use of modern agricultural technologies such as higher-quality seed of preferred varieties, agro-chemicals (chemical fertilizer, herbicides, and pesticides), and irrigation technologies (water wells and water pumps) among other items. As a result, yields per unit of land and labor have risen. However, there have been reports that increased production is reducing soil fertility, forcing many farmers to increase their use of urea and other chemical fertilizers in order to sustain their yields.

According to a survey, no fertilizer has been applied to rice production in the district so far. Farmers, on the other hand, have started applying fertilizer in recent years as yields on their plots have declined (Hagos et al., 2014). Despite the fact that no fertilizer was used ten years ago, all farmers now use fertilizer, according to this report. Disease and pest infestation have reduced yield production, necessitating a significant change in fertilizer application. Fertilizer problems such as cost and availability are a source of dissatisfaction for farmers (Tegegne and Mathias 2012).

\section{Benefits recognized from using artificial inputs}

Artificial inputs, according to respondents, resulted in higher rice crop yields. Besides, the hay provided after the rice crops were trashed was suitable for livestock feed. According to some evidence, chemically-based agriculture produces higher yields per area than "organic" traditional practices. However, this comes at a cost: high costs due to chemical and fuel inputs (Pimentel 2005), as well as numerous environmental effects that can be detrimental in the long run (Pimentelh 1996).

\section{Recognition of the negative impacts of artificial inputs used}

Artificial inputs, according to the respondents' observation point of view, have resulted in water contamination, a decrease in the number of birds, bee colonies, fish availability in the wetlands and Lake Tana, and other insects such as reptiles and amphibians in the study area's wetlands. Crop yields have increased as a result of the Green Revolution's major improvements in rice cultivation, but rice cultivation has become less sustainable as a result of eutrophication, fish kills caused by pesticide toxic effects, and biodiversity loss (Bambaradeniya, 2003). Rice field ecosystems rich in biodiversity exist in almost all rice-growing regions, according to Shimoda (2007), especially in areas where rice-growing intensification is impractical or impossible. Traditional rice systems were sufficiently multifaceted ecosystems that did not involve the use of chemical fertilizers and maintained a moderate but stable yield for thousands of years because a diverse array of microorganisms and other invertebrates allowed them to maintain soil fertility by recycling nutrients for rice cultivation, in contrast to modern rice cultivation (Moorman and Breeman, 1978; Roger et al., 1991). Despite being flooded during the growing season, rice fields do not provide wetland habitat for wildlife or macroinvertebrates, as well as many other wetland ecosystem services including carbon sequestration and biodiversity protection (Stenert et al., 2009).

\section{Recession farming}

In the dry season of the year, farmers grow crops in the form of recession farming around wetlands and Lake Tana areas, as explained by $22 \%$ of the sampled household respondents. According to Sander (2011), recession farming is used in Ethiopia when the area gets flooded due to its past. Different types of crops are planted, planting techniques are used, and the combination of other flood-related sources of income (fishery, for example) and strategies for coping with the risks are used differently across Ethiopia. The major regions where flood recession agriculture is considered to be practiced are Lake Tana, Baro-Akoba, Omo Valley, Wabi Shebelle, and Upper Awash. During the dry season, there are also a few small wetland areas where vegetables and other crops are grown on the drier parts. In the north of Ethiopia, flood-based farming is practiced along the shores of Lake Tana and along some of the tributaries that feed the lake. The Fogera floodplain, east of Lake Tana, revealed that the flood-prone area subject to flood recession farming year to year. The key anthropogenic problems are recession agriculture, unplanned urbanization, rapid population growth, indiscriminate manufacturing and construction

Page 16/30 
activities, disposal of domestic and industrial hazardous wastes, and free grazing. Many people in the lake subbasin already consider wetlands to be unsafe breeding grounds for disease vectors. The ecological and socio-economic values of activities near Lake Wetland destruction and conversion for recession are seldom considered. Agriculture continues to be considered a technologically advanced mode of development (Ibrahim and Minwyelet 2018)

\section{Impacts of recession farming}

The effects of recession farming on wetland and lake resources have been demonstrated, with papyrus, grass, birds, amount of water, the color of water, increased siltation, turbidity of the water, and other resources being decreased over time. According to the interviewed and FGD participants, there was a decline in water level in the wetland, fish, depletion of papyrus and other grass species, drying of the wetland, hippopotamus population, birds, and other wetlands issues. Recession farming has had a detrimental effect on the fauna, flora, and hydrology of the study site. New lands were developed at the land/swamp interface as a result of the recession and the draining of wetlands, resulting in major destruction of the wetland environment. Several studies have found a gradual shift in farming system enterprises from terrestrial to wetland-based development by households close to wetlands (Kairu 2001; Kipkemboi 2006). Aside from better land-use practices, other anthropogenic activities that have become more severe include livestock overgrazing and macrophyte overharvesting, both of which play a synergistic role in setting inertia of deterioration likely to disrupt the area's hydrological cycle and microclimate regulation. As wetland macrophyte vegetation disintegrates due to over-exploitation and loss of wetland vegetation, pollutants and nutrients are transported directly into the lake (Odada et al., 2004; Raburu and Okeyo-Owuor 2005).

The euphotic zone in littoral areas lakes shallows due to increased turbidity caused by the destruction of the buffer zone, suggesting a drastic drop in water quality. This had a significant negative impact on the attractiveness of the local tourismbased economy (Ayalew 2010).

\section{Wetland conservation issues of Fogera}

Wetland conservation is very important to the people who live in the Fogera wetlands and the surrounding region of Lake Tana. They said that conserving the Fogera wetland would save resources such as papyrus, fish, birds, and grass, as well as providing clean water, a moderate climate, reduced flooding, increased soil fertility, a large amount of water, increased biodiversity, fish hatcheries, and nursery areas, erosion control, nitrogen retention, groundwater recharge, and recreational activities, habitat for hundreds of species of animals and birds, the first line of defense against pollution from surface water runoff, increasing different insects like bees, etc. Rice paddies, coastal grazing marshes, recession agriculture and aquaculture in large floodplains, and cropping of small seasonal wetlands are examples of wetlands that provide food and other agricultural products http://www.ramsar.org/sites/default/files/wwd14_leaflet_en.pdf. Rice (Oryza sativa) habitats are important for the survival of certain waterfowl species. Traditional wetland rice farming has proven to be highly competitive in terms of yield sustainability and wetlands fauna and flora preservation. Moderate but steady yields have been sustained for thousands of years with no negative effects on the climate.

\section{Hydrological Alteration}

Seasonal and annual variations in the hydrological functions of the study wetlands were observed. The study of wetland water flow and rainfall patterns are both similar. In the study region, there is a strong association between water flow and rainfall $(r=.868 * \star, N=35$ at $\mathrm{P}<.000)$. In river ecosystems, hydrological regimes create biotic diversity, and hydrological variation is recognized as a primary driving force (Taylor et al., 2003). When humans alter the flow regime, the normal cycle of hydrologic variation and ecosystem dynamics is disturbed (Dunne and Leopold 1978; Poff et al., 1997).

Page $17 / 30$ 


\section{Conclusion}

Wetlands are the ultimate groundwater recharge areas because they not only absorb rainwater and make it usable for percolation, but they also play an important role in water purification, nutrient preservation, flood prevention, and erosion control. As a consequence, they're also known as "landscape kidneys." Changes in wetland hydrology can affect soil chemistry as well as the plant and animal population in wetlands. Altering the natural amount of water entering a wetland or the cycle of saturation and inundation will cause the environment to shift from a wetland to another.

They have high biodiversity and are connected to the food and water protection of the region. The findings of this study indicate that the spatial and temporal trends in crop production patterns in the area have increased because of the rice crop introduction in the Fogera floodplain. This introduction and expansion of rice farming in the study area were at the expense of wetland and grazing land losses. These indicated as there is an extended rice farming practice through recession farming. Moreover, farmers in the study area have also tried to maximize their rice yield with its intensification. Hence, for the intensification purpose farmers were used artificial inputs which were not used before the introduction of rice crop in the area. These artificial inputs like fertilizer, pesticides, insecticides, and herbicides have an impact on water pollution and soil degradation. These inorganic chemicals can also affect the aquatic ecosystems of the wetlands and lake. Generally, these extended and intensification of farming practices have an impact on the biodiversity of fauna and flora of the area. Moreover, these anthropogenic problems coupled with rainfall variability could be a cause for hydrological alteration of the study area.

\section{Declarations}

\section{Acknoledgment}

The authors acknowledge Addis Ababa and Wollo University for giving this chance to do this project, I would like to thank Fogera Woreda Agriculture office for providing me information and secondary data and development agents for assisting me in collecting data.

\section{Declaration}

\section{Funding}

Not applicable

\section{Conflicts of interest}

The authors declare that there is no any financial and non-financial competing interest

The authors declare that they have no any competing interests

\section{Ethics approval}

Not applicable

Consent to participate

Not applicable

\section{Consent for publication}

Not applicable 


\section{Availability of data and materials}

All data produced from this study are provided in this manuscript.

\section{Code Availability}

Not applicable

\section{Authors Contribution}

Mare Addis Desta is the corresponding author who designed the research, developed the data collection tools, collected the data, analyzed the data, and participated in writing the paper. Dr. Gete Zeleke is my advisor for this paper. He is $2^{\text {nd }}$ co-author that contributed to guiding and shaping the research. He has also a high contribution to editing the paper. William A. Payne is a professor that he has contributed to this paper by giving a chance to visiting scholar in the USA. He gave me a computer and office with its equipment to facilitate this research. He has also contributed to editing the paper. Mr. Wubneh Belete has contributed to this paper in editing the manuscript. Generally, all co-authors contributed to guiding the researcher and editing the paper. All authors read and approved the final manuscript.

\section{References}

Abaye A. (2007) Vegetable market chain analysis in Amhara National Regional State: The case of Fogera woreda, South Gondar zone. An MSc Thesis Presented to the School of Graduate Studies of Haramaya University

Agegnehu S, Fikremariam A, Agumas B, Eshetie A, Minwuyelet J, Getachew A. (2013) Effect of time and frequency of hand weeding on yield of direct seeded rice in Fogera plain. Currt Res Microbiol Biotechnol 1(6):266-269

Astewel T. (2010) Analysis of Rice Profitability and Marketing Chain: The case of Fogera Woreda, South Gondar Zone, Amhara National Regional State, Ethiopia. Thesis of Master of Science in Agriculture (Agricultural Economics), Haramaya University

Ayalew W. (2010) Improving management of shoreline and riparian wetland ecosystems: the case of Lake Tana catchment. Ecohydrology for water ecosystems and society in Ethiopia, ecohydrology hydrobiology, DOI: 10.2478/v10104-011-0017-4 Vol. 10 No. 2-4, 123-132

Bambaradeniya CNB. (2003) An overview of irrigated rice agro-ecosystems in Asia as man-made wetlands sustaining a rich biodiversity. International Journal of Ecology and Environmental Sciences 29: 29-38.

Central Statistical Agency CSA (2007) Ethiopia, Statistical abstract, Addis Ababa

Dugan P J (1990) Wetland conservation: a review of current issues and action IUCN, Gland

Dunne T, Leopold LB. (1978) Water in environmental planning. W. H. Freeman and Co., San Francisco

Gebey, T., Berhe, K., Hoekstra, D. and Alemu, B. (2012) Rice value chain development in Fogera woreda based on the IPMS experience. Nairobi, Kenya: ILRI.

Gebey, T., Berhe, K., Hoekstra, D., \& Alemu, B. (2012) Rice value chain development in Fogera woreda based on the IPMS experience.

Gomiero, Tiziano; Pimentel, David; Paoletti, Maurizio G. (2011) Environmental Impact of Different Agricultural Management Practices: Conventional vs. Organic Agriculture. Critical Reviews in Plant Sciences, 30(1-2), 95-

124. doi:10.1080/07352689.2011.554355

Page $19 / 30$ 
González-Betancourt, M. and Mayorga-Ruíz L. (2018) Normalized difference vegetation index for rice management in El Espinal, Colombia. DYNA, 85(205), pp. 47-56, DOI: http://doi.org/10.15446/dyna.v85n205.69516

Gosselink, J. G. and R. E. Turner (1979) The role of hydrology in freshwater wetland ecosystems. P. 63-78. In Good, R. E., D. F. Whigham, and R. L. Simpson (eds.) Freshwater Wetlands Ecological Processes and Management Potential. Academic Press, New York, NY USA.

Hagos Gebresllassie, Temesgen Gashaw and Abraham Mehari (2014) Wetland Degradation in Ethiopia: Causes, Consequences and Remedies. Journal of Environment and Earth Scien, ISSN 2224-3216 (Paper) ISSN 2225-0948 (Online) Vol.4, No.11, 2014, www.iiste.org

Ibrahim Mohammed and Minwyelet Mengistu (2018) Status, Threats and Management of Wetlands in the Lake Tana Subbasin: A Review. Journal of Agriculture and Environmental Sciences (JAES), Vol 3, No 2

(2018) https://journals.bdu.edu.et/index.php/jaes/issue/view/26

Improving Productivity and Market Success (IPMS) (2005) Fogera wereda pilot learning site diagnosis and program design.

Indicators of Hydrological Alteration (IHA) Version 7.1.

Jiangxiao Qiu and Monica G. Turner (2013) Spatial interactions among ecosystem services in an urbanizing agricultural watershed Department of Zoology, University of Wisconsin, Madison, WI 53706

Johnson, L B, Richards, C, Host, G E and Arthur, J W (1997) 'Landscape influences on water chemistry in Midwestern stream ecosystems', Freshwater Biology 37:194-208.

Kairu JK (2001) Wetland use and impact of Lake Victoria, Kenya region. Lakes Reserv.: Res. Manage., 6:117-125

Kawano S. (2000) Nakaikemi, a miraculous lowland marsh in Central Honshu, Japan - a search for the secret of its fascination, Japan.

Kipkemboi J (2006) Finger ponds: Seasonal integrated aquaculture in East African freshwater wetlands. Exploring their potential for wise use strategies. PhD dissertation, Institute if Water Education and IHE-Delft, Netherlands.

Millennium Ecosystem Assessment (MEA) (2005) Ecosystems and human well-being: wetlands and water Synthesis. Washington, DC: World Resources Institute.

Mitsch WJ, Gosselink JG (1986) Wetlands. Van Nostrand Reinhold, New York Moges MA, Schmitter P,

Mitsch, W J, and J G Gosselink (2000) Wetlands, Third edition, John Wiley and Sons, New York. Murray-Darling Basin Commission 2001, Rivers as Ecological System: The Murray-Darling Basin, Ed. W.J Young.

Moorman, F. R. \& Van Breeman, N. (1978) Rice: Soil, Water, Land. pp. 185. Los Baños, Philippines: International Rice Research Institute

Mulugeta S, Heluf G. (2006) Effects of N and P fertilizers on yield and N uptake of flooded rice grown on vertisols of Fogera plain of Ethiopia. Indian J Fertilizers 1(1):47-51

Odada EO, Olago DO, Kulindwa K, Ntiba M, Wandiga S. (2004) Mitigation of environmental problems in Lake Victoria, East Africa: causal chain and policy options analyses. Ambio, (1-2):13-23.

P.A. Roger, K.L. Heong \& P.S. Teng (1991) Biodiversity and Sustainability of Wetland Rice Production: Role and Potential of Microorganisms and Invertebrates. International Rice Research Institute, Manila, Philippines

Page 20/30 
Pimentel D, Hepperly P, Hanson J, Douds D, Seidel R. (2005) Environmental, energetic, and economic comparisons of organic and conventional farming systems. BioScience; 55(7): 573-582.

Pimentel D. (1996) Green revolution agriculture and chemical hazards. Sci Total Environ; 188: S86-S98.

Poff NL, Allan JD, Bain MB, Karr JR, Prestegaard KL, Richter BD, Sparks RE, Stromberg JC. (1997) The natural flow regime. Bioscience 47(11):769-784

Raburu PO, Okeyo-Owuor JB. (2005) Impact of agro-industrial activities on the water quality of the River Nyando, Lake Victoria Basin, Kenya. In. Odada et al., (eds.) Proceedings of the $11^{\text {th }}$ World Lakes Conference. 31 st Oct. -4 th Nov. 2005 , Nairobi, Kenya, 2: 307-313.

RAMSAR, FAO and IWMI (2014) Wetlands \& Agriculture: Partners for Growth. World Wetlands Day 2 February, http://www.ramsar.org/).

Roger P. A. (1996) Biology and management of the floodwater ecosystem in rice fields. International Rice Research Institute, P. O. Box 933, Manila 1099, Philippines. 250 p.

Rosenberg, D.M., McCully, P. and Pringle, C.M. (2000) Global- Scale Environmental Effects of Hydrological Alterations: Introduction. Bioscience, 50 (9), 746-751. Smakhtin,

Sander Nederveen, Abebe Mengistu en Frank van Steenbergen, with contributions of Tena Alamirew and Yohannes Geleta (2011) Flood Based Farming Practices Status and Potential in Ethiopia: Overview Paper Spate Irrigation Network. www.spate-irrigation.org.

Shimoda M. (2007) Conservation and management of rice field biodiversity. In: Okruszko T, Maltby E, Szatylowicz J, Miroslaw-Swiatek D, Kotowski V. eds. Wetlands: monitoring, modelling and management. London: Taylor and Francis, 323329.

Stenert, C.; Bacca, R. C.; Maltchik, L.; Rocha, O. (2009) Can hydrologic management practices of rice fields contribute to macro-invertebrate conservation in southern Brazil wetlands? Hydrobiologia 2009, 635, 339-350.

Taylor, V., Schulze, R., \& Jewitt, G. (2003) Application of the Indicators of Hydrological Alteration method to the Mkomazi River, KwaZulu-Natal, South Africa. African Journal of Aquatic Science, 28(1), 1-11. doi:10.2989/16085914.2003.9626593

Tegegne Misganaw, Mathias Becker (2019) "Assessment of Socio-Economic and Agronomic Characteristics Influencing Variety Choice in Rice Based Farming System in Fogera, Ethiopia" International Journal of Research Studies in Agricultural Sciences (IJRSAS), 5(12), pp. 27-34, http://dx.doi.org/10.20431/2454-6224.0512004

Tilahun T, Nigussie D, Wondimu B, Setegn G (2013) Effect of transplanting on terminal moisture stress, growth and yield of rain-fed lowland rice. Res J Agric Environ Manage 2(4):117 -129 ISSN 2315-8719@ 2013 Apex Journal International, Available online at http://www.apexjournal.org

Tiner, R W. (1993) 'The primary indicators method - a practical approach to wetland recognition and delineation in the United States', Wetlands 13(1):50-64.

Tucker, C. J., and P. Sellers. (1986) Satellite remote Sensing of primary production. International Journal of Remote Sensing 7:1395-1416.

Yamane, T. (1967) Statistics: An Introductory Analysis. 2nd Edition, Harper and Row, New York.

http://www.ramsar.org/sites/default/files/wwd14_leaflet_en.pdf

Page 21/30 
http://www.ramsar.org/sites/default/files/wwd14_leaflet_en.pdf

https://doi.org/10.5067/ASTER/ASTGTM.003)

\section{Figures}

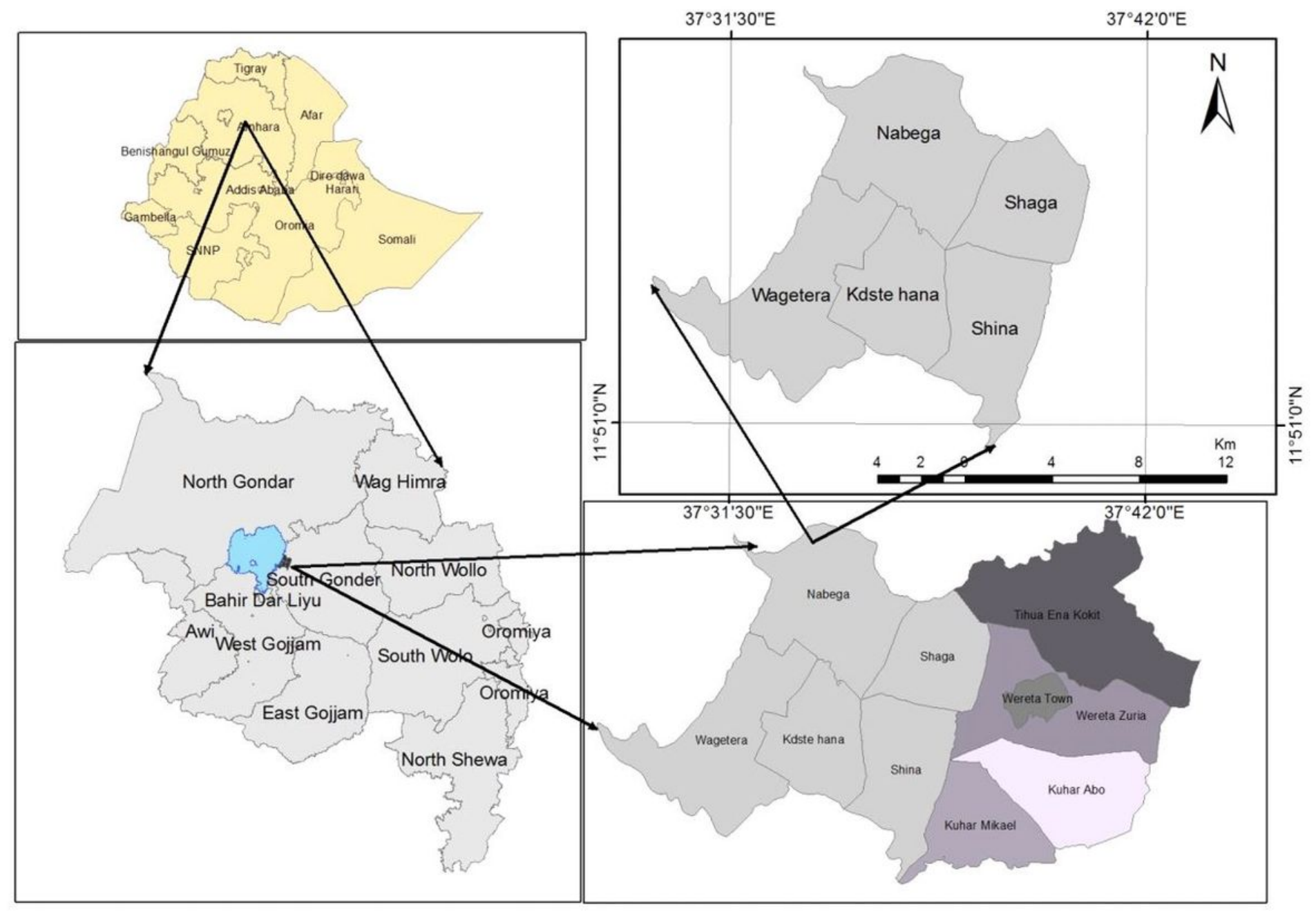

Figure 1

Map of the study area 


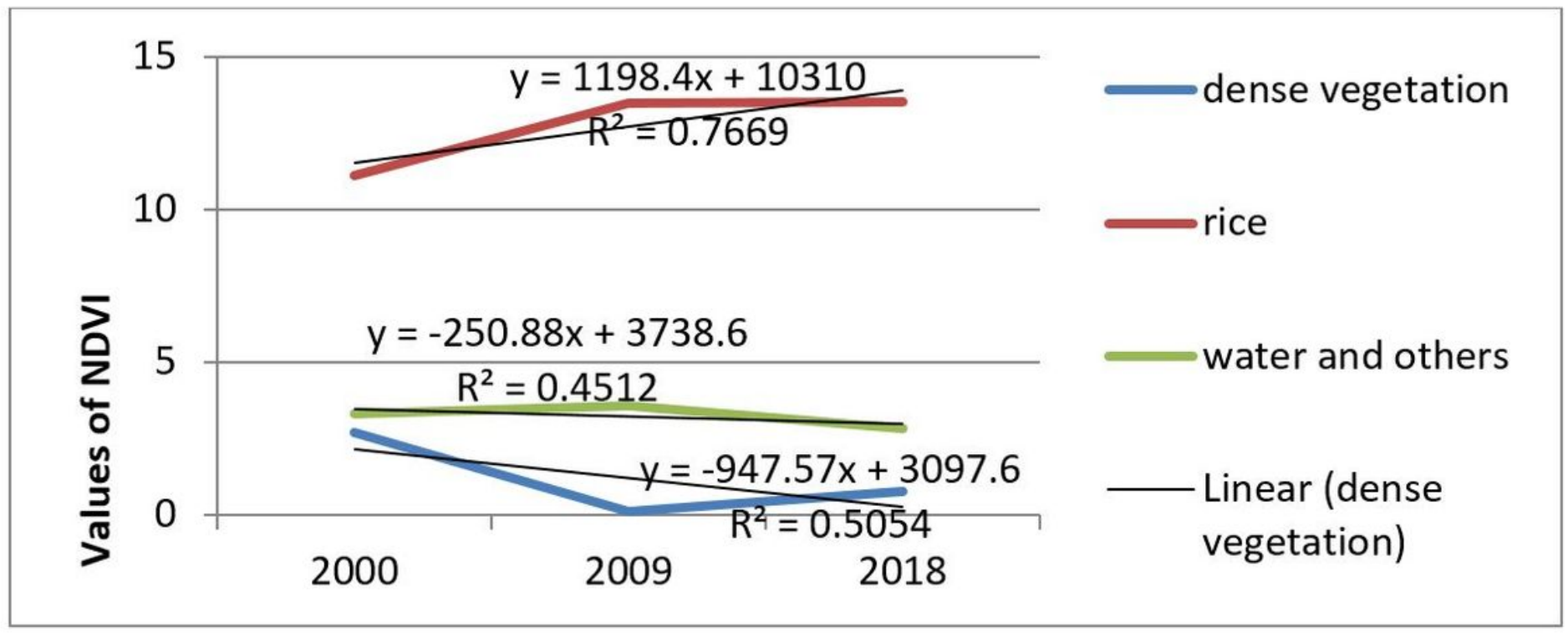

Figure 2

Graph of trend analysis based on NDVI

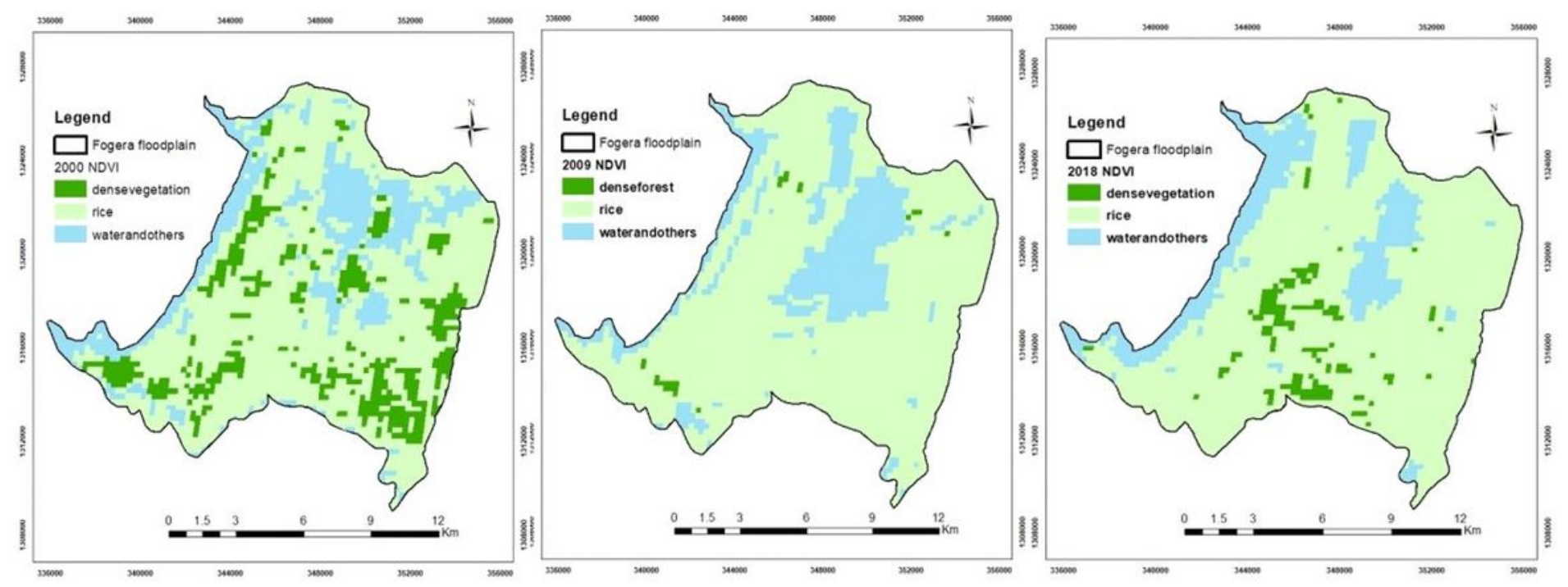

Figure 3

NDVI trend Maps $(a, b, c)$ left to right

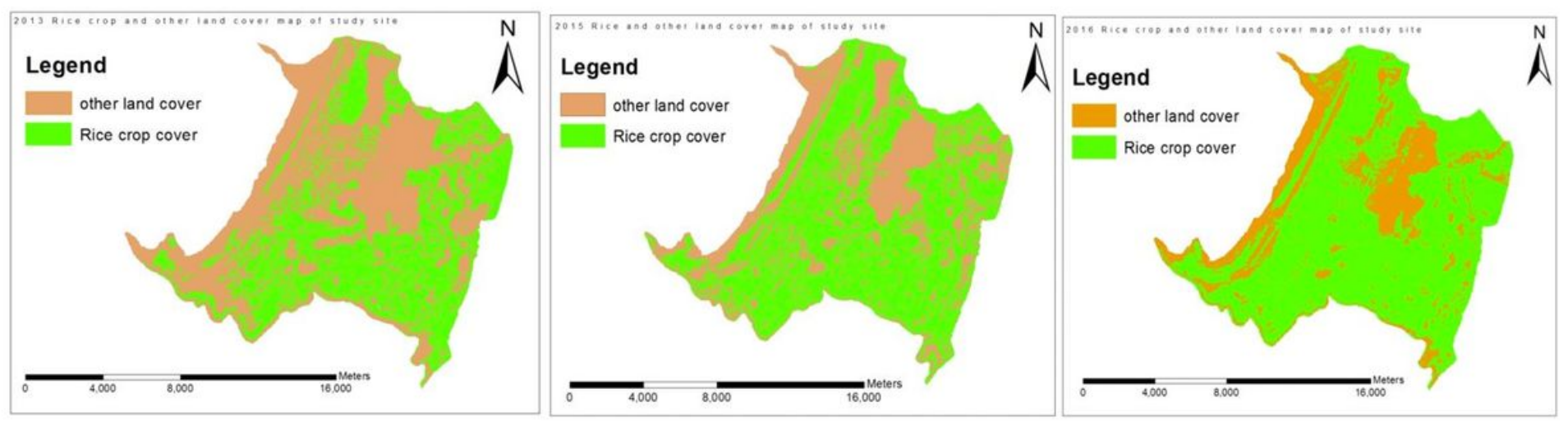




\section{Figure 4}

Rice verse other land use in Fogera floodplain

\section{Total in \%}
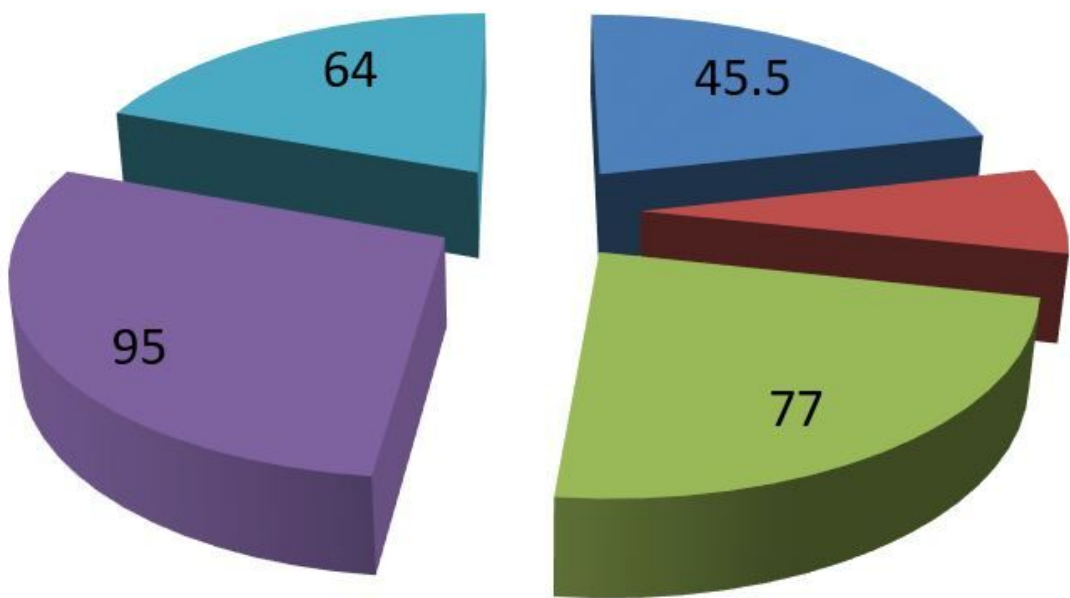

Fertilizer

23

- improved seed

local seed

pesticide

herbicide

\section{Figure 5}

The inputs used to increase their rice yield

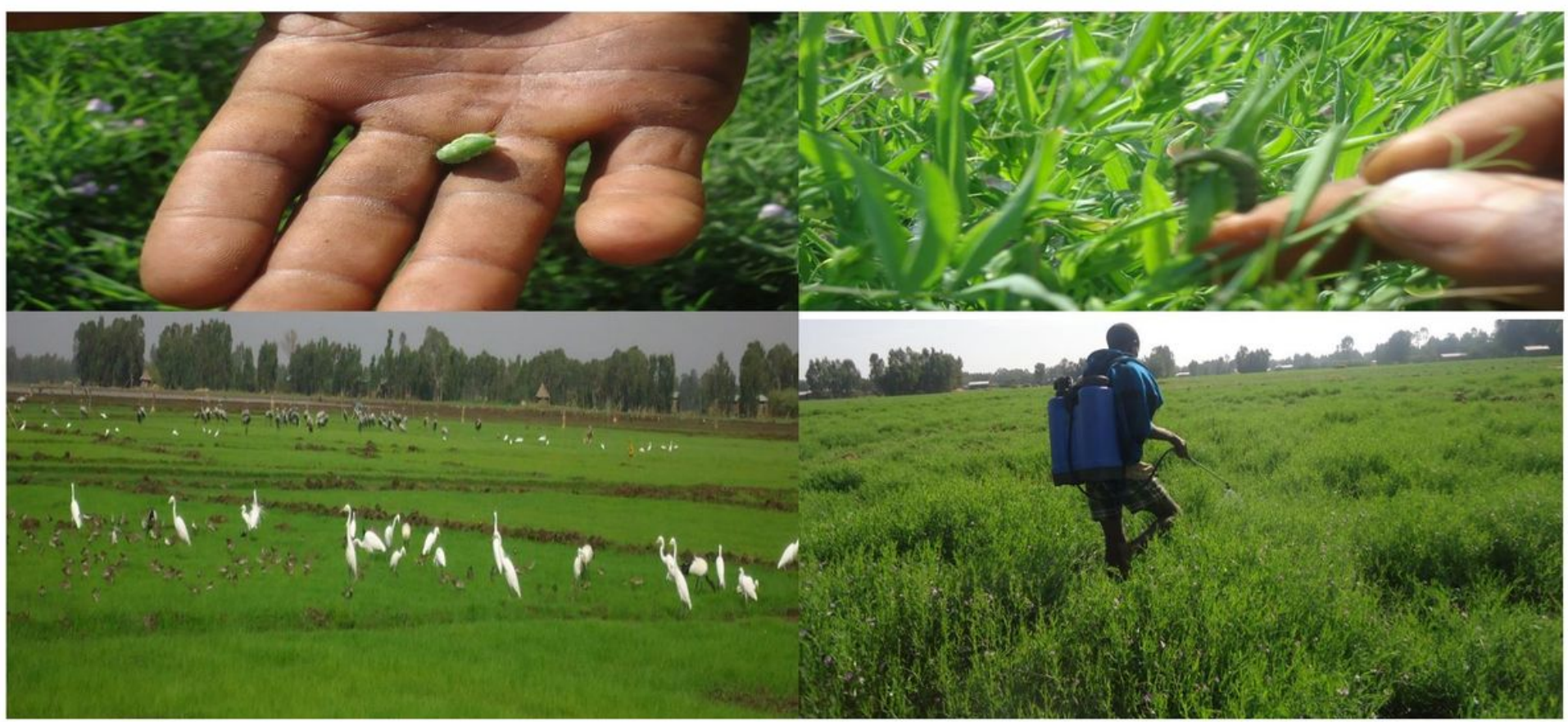

\section{Figure 6}



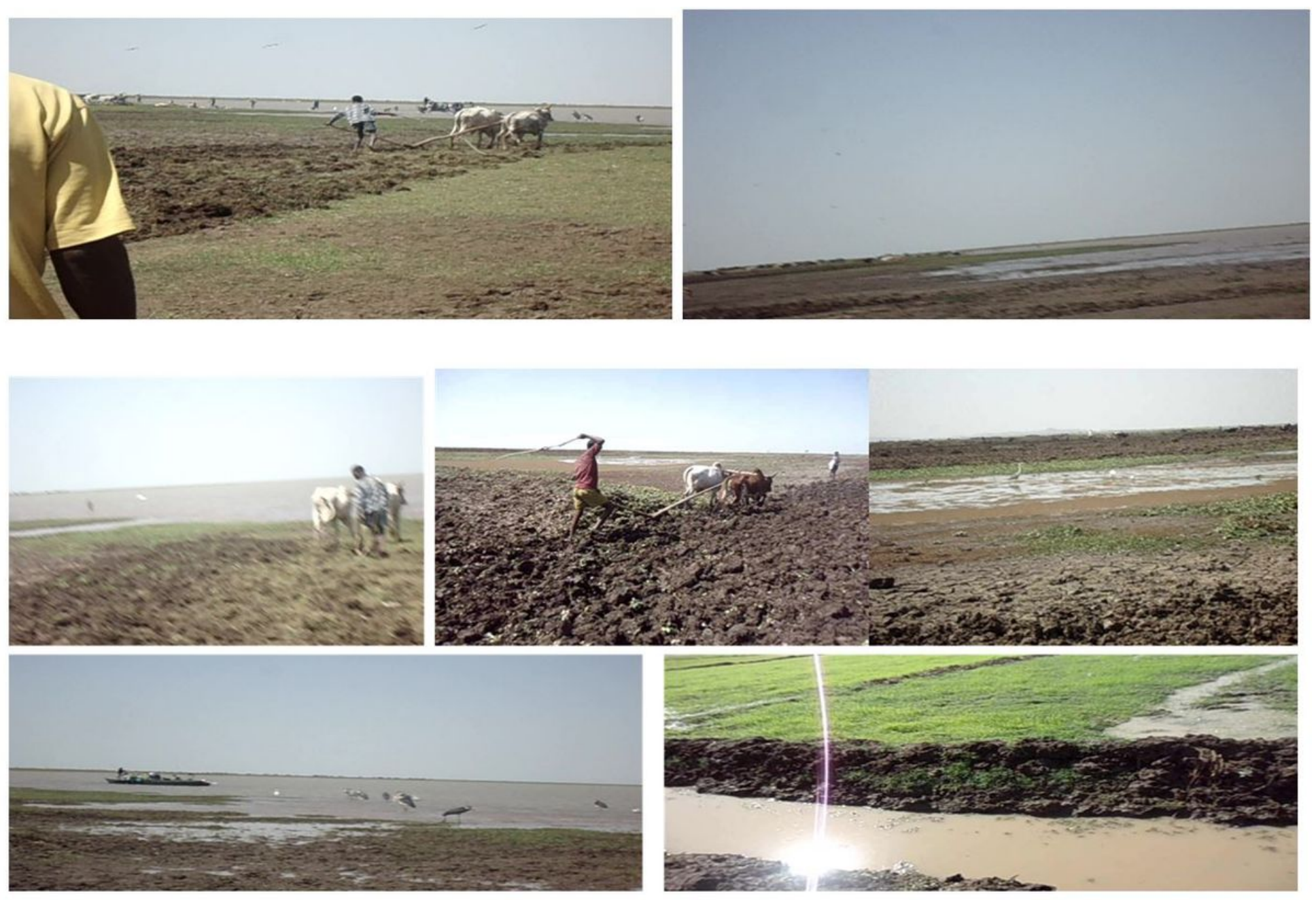

\section{Figure 7}

Recession farming near Lake Tana and wetlands
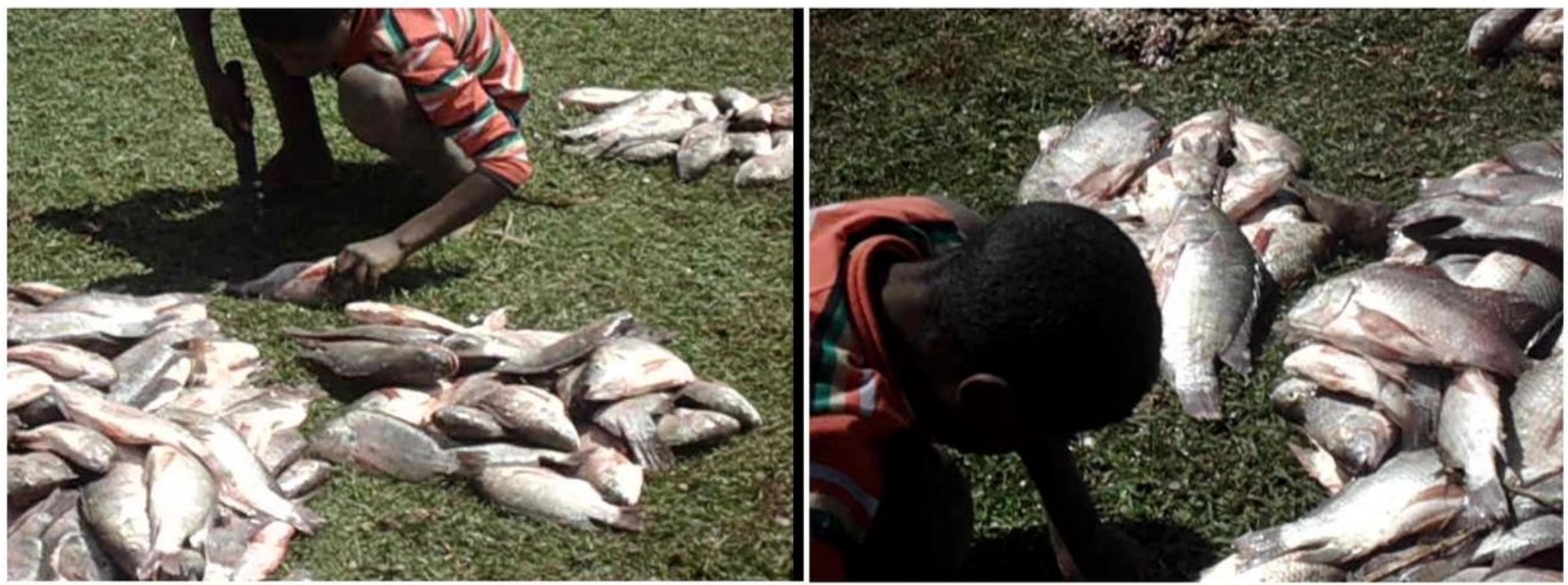

Figure 8

Fish harvest locally in Lake Tana at eastern shore 


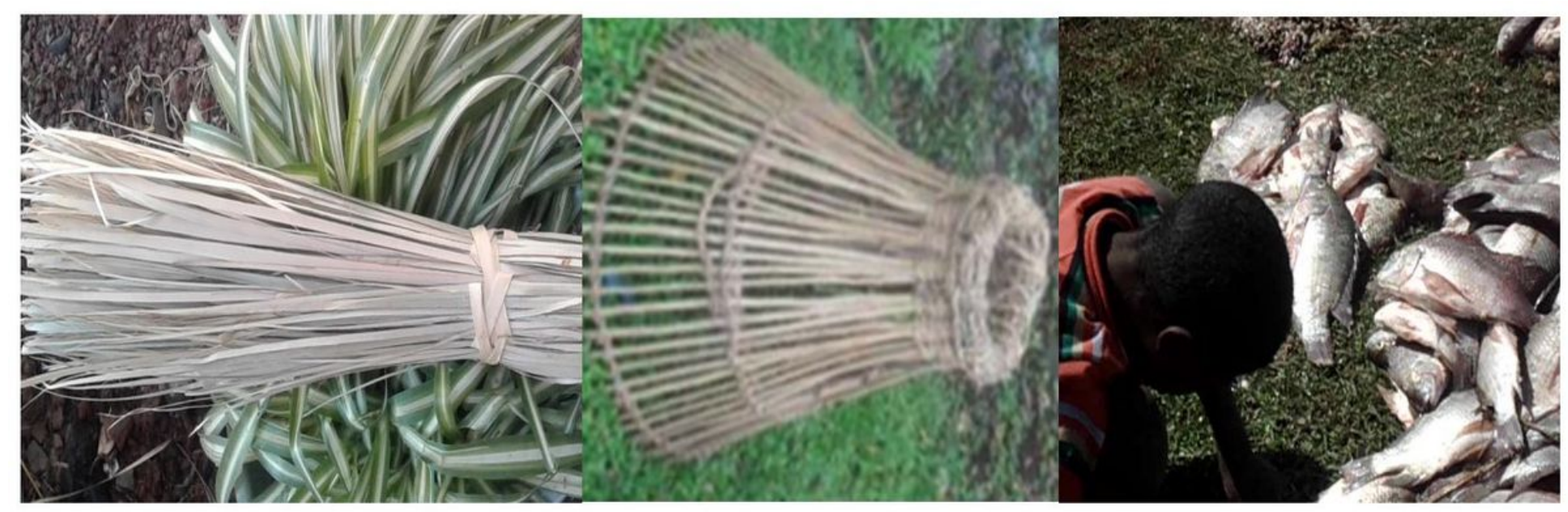

Figure 9

Cleaning material, fish trap and fish with fisherman (from left to right)

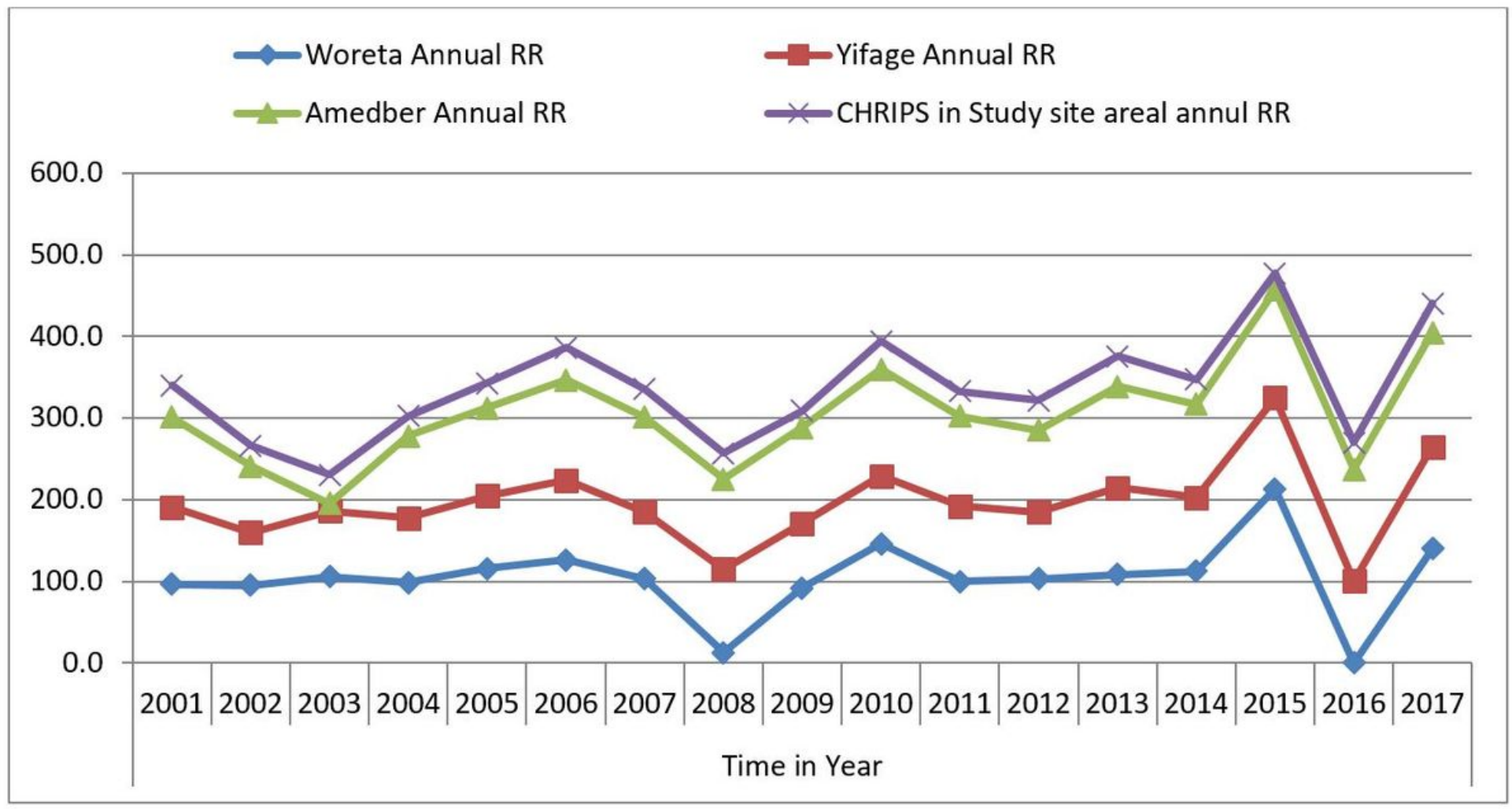

Figure 10

Annual rainfall of the study site 


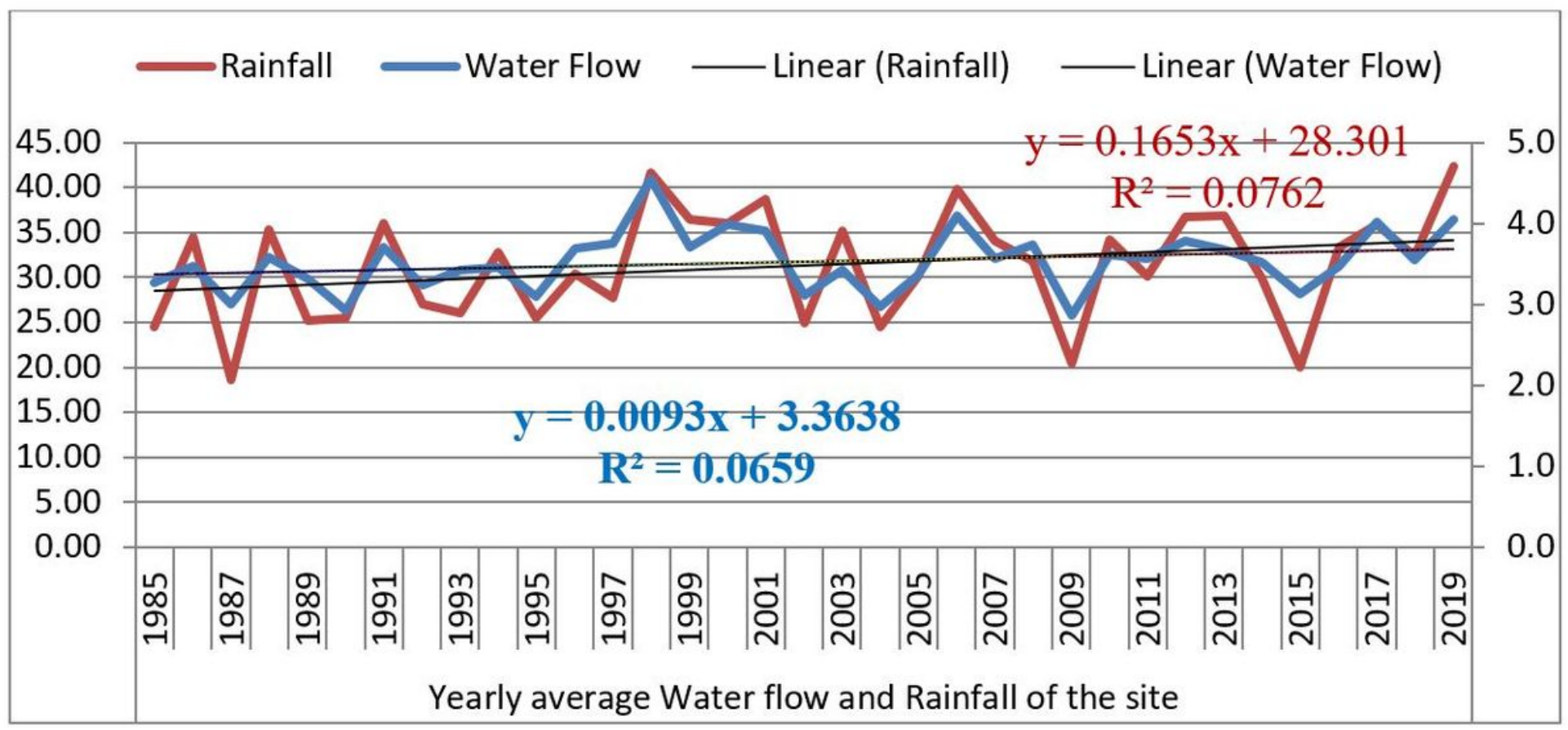

Figure 11

Yearly average water flow and rainfall of the study site

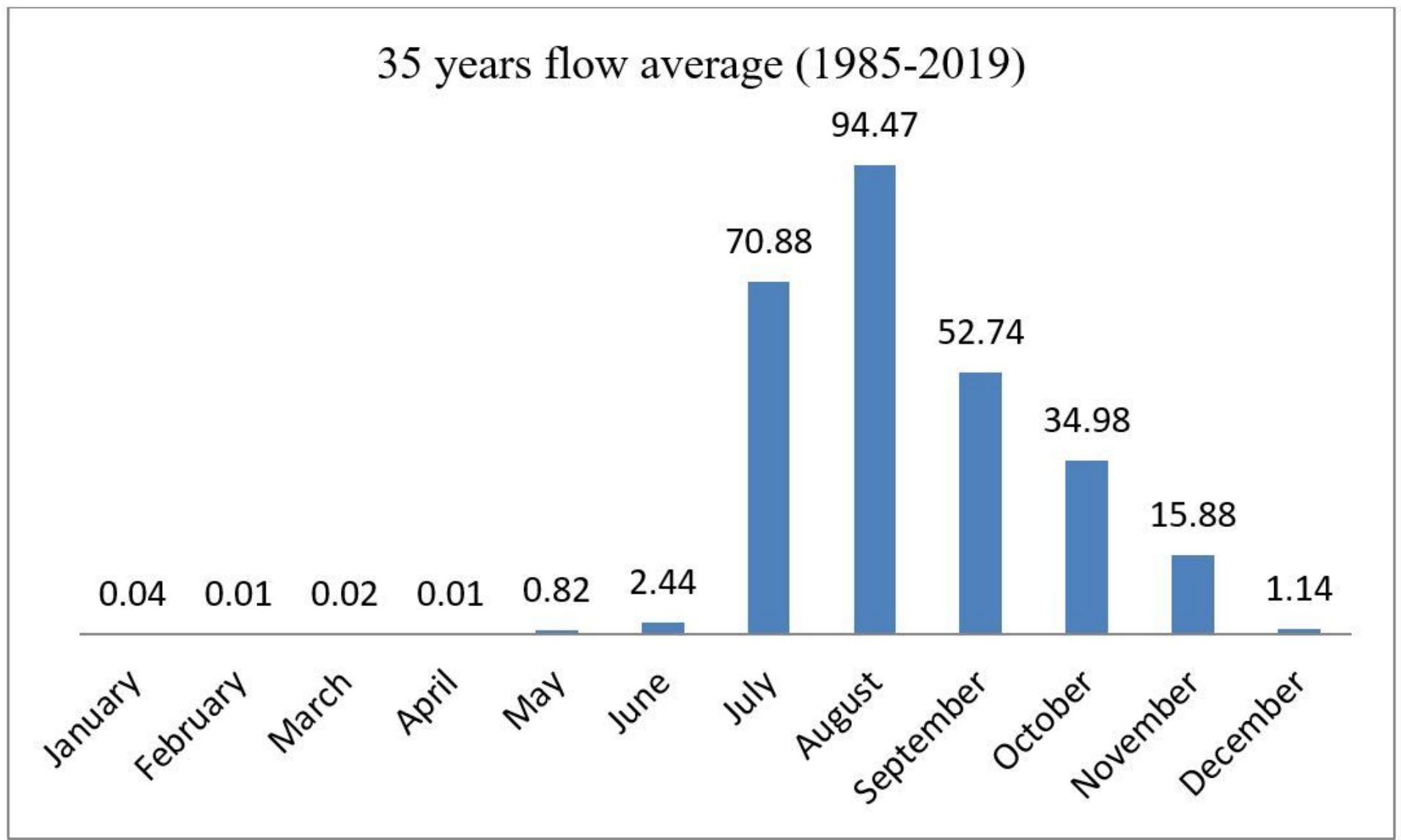

Figure 12

35 years flow average generated through (IHA) for the study area. 


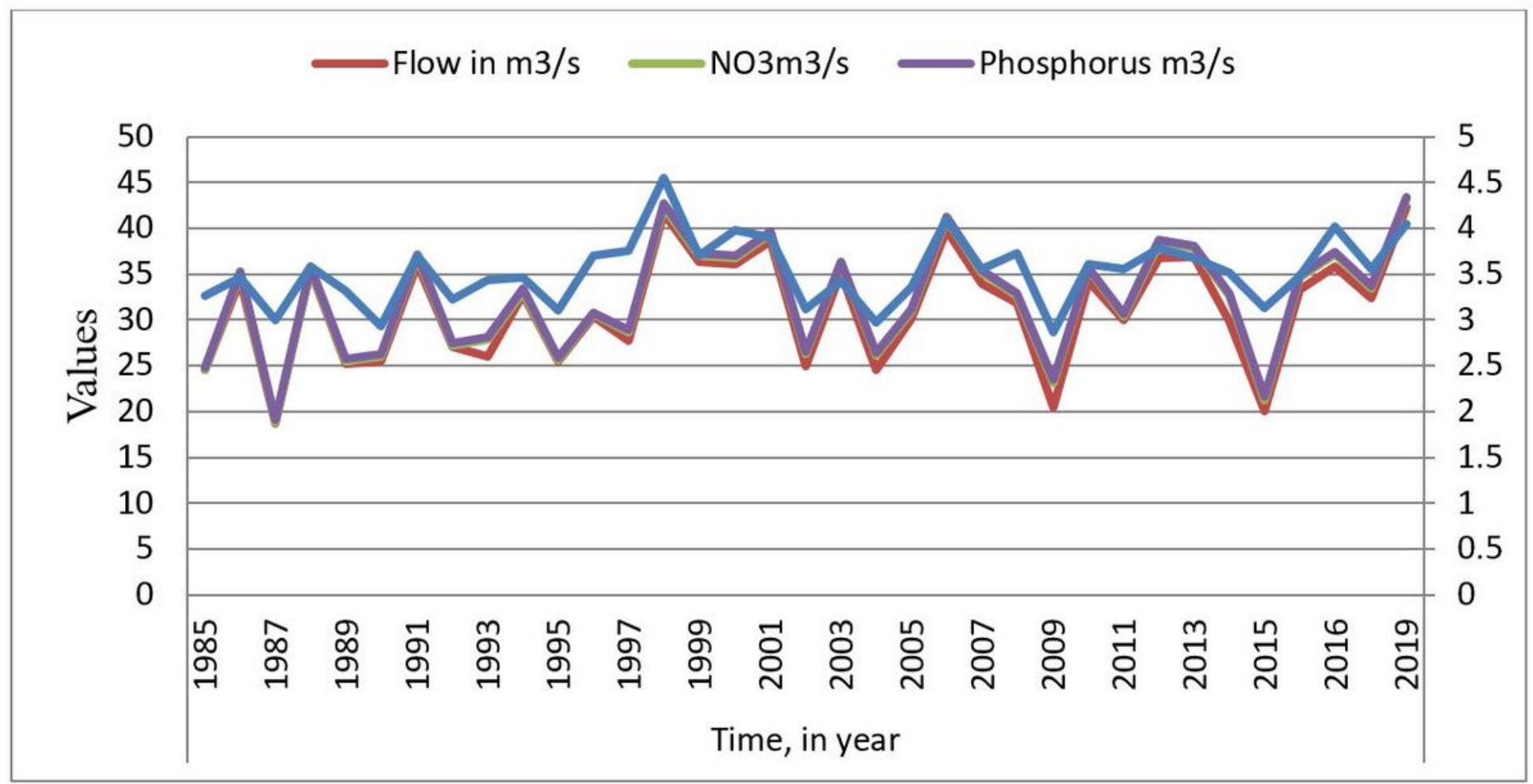

Figure 13

The patterns of Flow, No3 and Phosphorus 


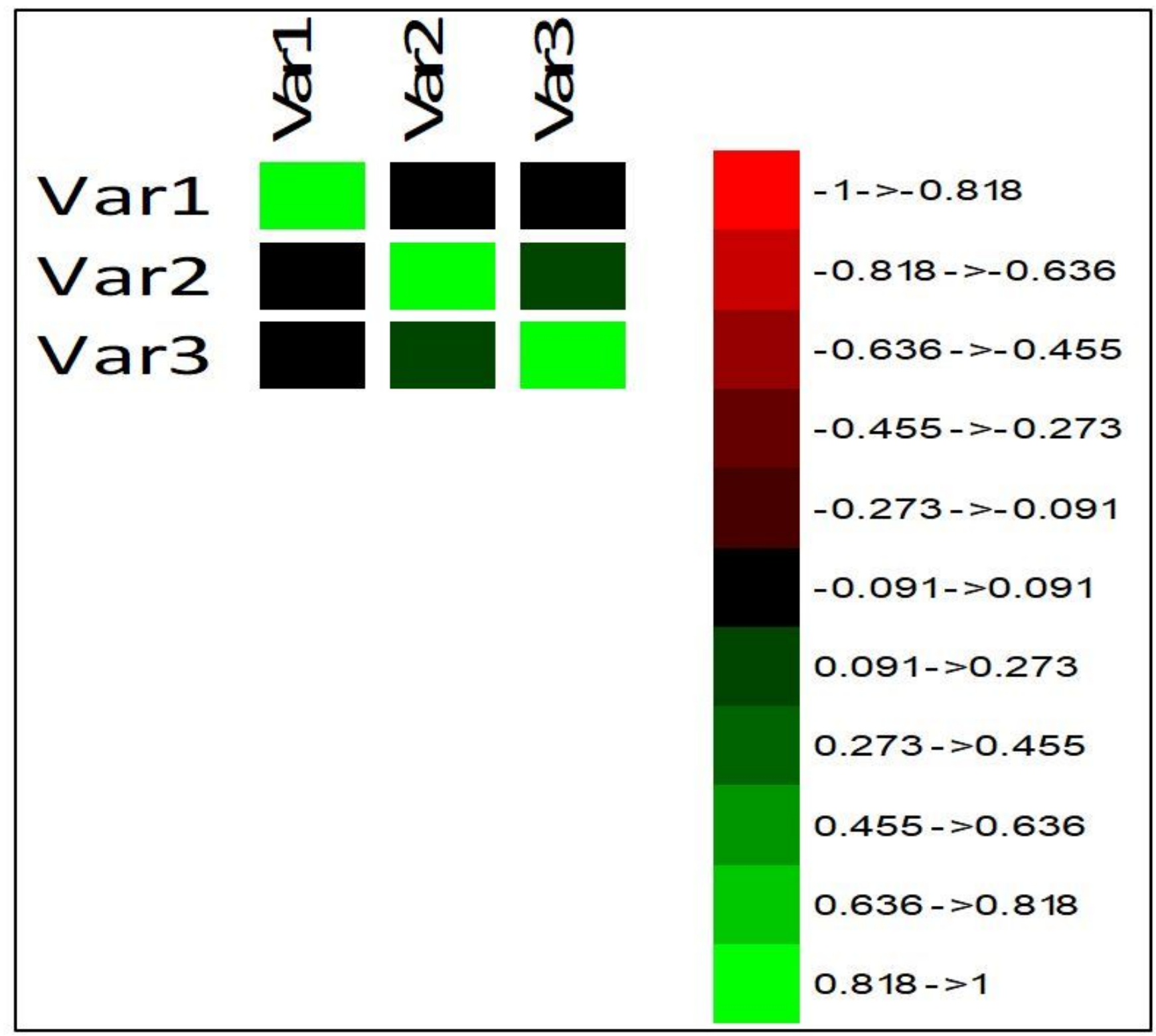

Figure 14

Image of the correlation matrix 


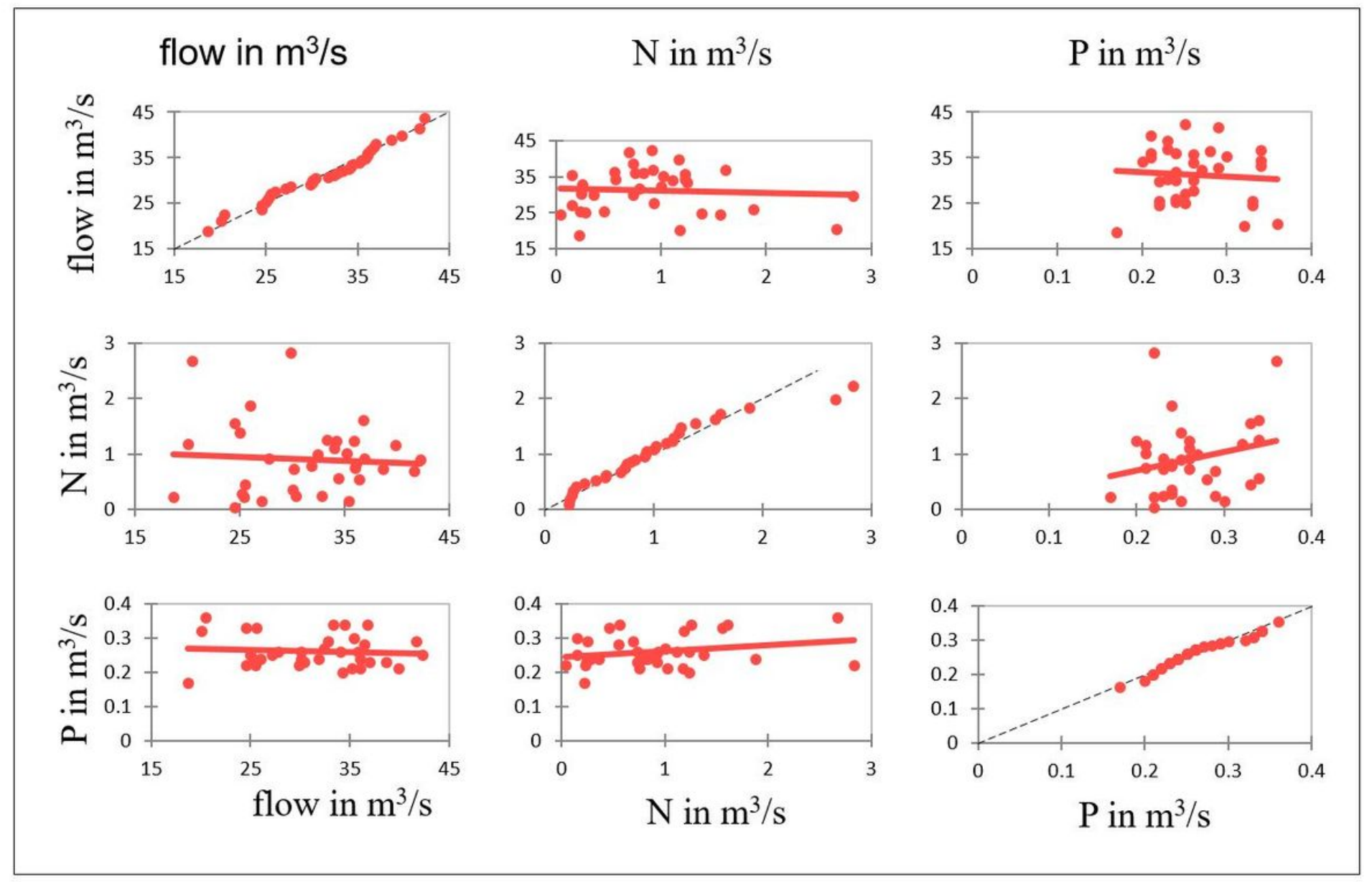

Figure 15

Correlation matrix graph 